\title{
Golden Parachutes, Takeover Probability, and Risk-Taking
}

Article in SSRN Electronic Journal · November 2011

DOI: $10.2139 /$ ssrn.1952869

CITATIONS

0

2 authors, including:

Dong Chen

University of Baltimore

17 PUBLICATIONS 80 CITATIONS

SEE PROFILE
READS

164

All content following this page was uploaded by Dong Chen on 17 June 2014. 


\title{
Golden Parachutes, Takeover Probability, and Risk-taking
}

\author{
Dong Chen $^{1}$ and Morgan J. Rose ${ }^{2}$
}

\begin{abstract}
This paper is the first to examine the relationships among golden parachutes (GPs), CEO compensation incentives, and managerial risk-taking. GPs are positively associated with risktaking, but only when controlling for the surprisingly negative interactions of GPs with CEO pay-volatility sensitivity (vega) and with pay-performance sensitivity (delta). These results appear consistent with the takeover probability hypothesis that a GP indicates a higher probability that a firm will be acquired, which increases the divergence between the CEO's incentives as a manager and as an equity owner. The hypothesis that these results are due to CEO entrenchment is not supported.
\end{abstract}

This draft: January 31, 2012

Keywords: golden parachute, corporate governance, risk-taking, pay-performance sensitivity, pay-volatility sensitivity, delta, vega, takeover probability

JEL Classification: G30, G34

\footnotetext{
${ }^{1}$ University of Baltimore. 1420 N Charles St, Baltimore, MD 21201. dchen@ubalt.edu, (410) 837-4919, (410) 8375722 (fax)

${ }^{2}$ University of Maryland, Baltimore County. 1000 Hilltop Circle, Baltimore, MD 21250. mrose@umbc.edu, (410) 455-8485, (410) 455-1054 (fax)
} 


\section{Introduction}

Golden parachutes (GPs) are severance agreements that provide a CEO with compensation pay if the CEO is fired, demoted, or resigns following a change in control. Although GPs are related to conventional severance agreements specifying the CEO's benefits and obligations in the event of her dismissal, the purposes and effects of GPs are somewhat more complicated due to conflicts among a CEO's incentives that may arise during a takeover attempt. ${ }^{3}$ Target firm stock returns tend to rise appreciably during a takeover, so a CEO with significant equity holdings in the firm has an incentive to welcome a takeover. The senior executives of a target firm generally lose their jobs after an acquisition, giving the target firm CEO the incentive to resist a takeover attempt even if it would be in the interests of the CEO as a shareholder. ${ }^{4}$ The divergence of the incentives of the CEO as a manager and the CEO as a shareholder makes the implications of GPs for firms, managers, and shareholders an ongoing source of debate and controversy. ${ }^{5}$

Given that divergence, it is perhaps unsurprising that a number of different purposes have been offered for GPs. Several papers argue that by insuring CEOs against losses in the event of a takeover, GPs reduce CEO resistance to takeovers and better align CEO interests to the interests of shareholders (e.g., Lambert and Larcker, 1985; Jensen, 1988; Ferreira et al., 2011). Others assert that takeovers allow for the expropriation by shareholders of CEO investments in firmspecific human capital (Knoeber, 1986; Falaschetti, 2002) or implicit deferred compensation (Agrawal and Knoeber, 1998), and that GPs reduce this threat to CEOs by raising the cost of

\footnotetext{
${ }^{3}$ For recent papers on severance agreements, see Berkovitch et al. (2000), Almazan and Suarez (2003), Rusitcus (2006), Yermack (2006), Inderst and Mueller (2010), and Goldman and Huang (2011).

${ }^{4}$ Hartzell et al. (2004) present evidence that nearly two-thirds of target firm CEOs leave their firms either at the time of or within one year of the acquisition. Their departures represent the end of their careers for a large majority of these CEOs. Two years after acquisitions, fifty-eight percent of all target firm CEOs in their sample were either retired, working for a government or non-profit organization, or the authors were unable to identify any subsequent positions.

${ }^{5}$ Chakraborty et al. (2007) and Kempf et al. (2009) examine managerial risk-taking in relation to diverging compensation and job retention incentives, although not in the context of takeovers or governance mechanisms.
} 
takeovers. Raising the cost of takeovers may also insulate CEOs from the discipline of the market for corporate control, which can facilitate managerial slack or rent extraction by entrenched CEOs (Shleifer and Vishny, 1989; Gompers et al., 2003; Bebchuk et al., 2009), or permit CEOs to focus more on long-term value creation relative to short-term returns (Stein, 1988).

We explore a purpose that has not been proposed previously, that GPs influence managerial risk-taking. Several recent papers examine non-GP severance agreements and CEO risk-taking (Ju et al., 2003; Brown et al., 2011; Cadman et al., 2011; Huang, 2011). As noted above, GPs are distinct from those severance agreements because GP payments are associated specifically with changes in control, and takeover attempts may exacerbate the conflicting incentives of CEOs as managers versus as equity owners. As a result, risk-taking may relate quite differently to GPs than to severance agreements, distinguishing our paper from those just cited.

Many early empirical investigations of GPs concerned market returns to the adoption of GPs, with some finding positive reactions (Lambert and Larcker, 1985), some negative (Mogavero and Toyne, 1995; Hall and Anderson, 1997), and some finding no significant reactions (Born et al., 1993). Despite the arguments above that the protection of CEOs offered by GPs can result in improved firm performance, Bebchuk et al. (2009) and Bebchuk et al. (2010) find negative associations between GPs and Tobin's Q, consistent with CEO entrenchment. Subramaniam and Daley (2000) document a positive relationship between GPs and overinvestment in capital assets. Several papers investigate the relationship between GPs and the probability of a takeover, with Born et al. (1993), Machlin et al. (1993), and Bebchuk et al. (2010) all finding a positive relationship, and Cotter and Zenner (1994) and Hall and Anderson (1997) not. With the exception of Bebchuk et al. (2010), all of these papers on GPs and takeover probability use 
samples from the 1980s. Our work, of which the relationship between takeover probability and GPs is an important component, utilizes more recent data.

Specifically, this paper uses a sample of S\&P 1,500 firms (excluding dual-class, financial, and utility firms) between 1992 and 2006 to examine the relationship between GPs and managerial risk-taking, as well as how GPs and managerial compensation incentives interact to influence risk-taking. We also present evidence that the channel through which GPs influence managerial risk-taking is the probability of takeovers, as opposed to a connection between GPs and CEO entrenchment. To our knowledge these topics are previously unexplored, and therefore our findings (described below) represent original contributions to the financial literature.

Intuition suggests that because GPs insure CEOs against losses related to their firms being taken over, and the probability of a takeover is negatively associated with firm performance, GPs offer CEOs insurance against the potential negative consequences of risk-taking. ${ }^{6}$ As such, GPs may be expected to be positively associated with risk-taking. This would be consistent with recent empirical and theoretical work finding a positive relationship between severance agreements and risk-taking (Ju et al., 2003; Brown et al., 2011; Cadman et al., 2011; Huang, 2011). However, our initial results find no significant relationship between GPs and managerial risk-taking, as captured by four different measures of stock return and earnings volatility. ${ }^{7}$

We also find that compensation incentives, namely the sensitivity of CEO wealth to firm stock price (delta) and stock return volatility (vega), are negatively associated with risk-taking, controlling for lagged values of the risk-taking variables. These results are consistent with some, but not all, previous literature. Coles et al. (2006) find that higher vega is associated with riskier

\footnotetext{
${ }^{6}$ Bebchuk et al. (2010) find a negative relationship between Tobin's Q and the probability of a firm being a takeover target. Billet and Xue (2007) and this paper (see Table 4) find a negative relationship between market-to-book ratio and takeover probability.

${ }^{7}$ See Appendix Table A1 for definitions of the variables used in our analysis.
} 
corporate policy choices, with delta associated with either more or less risky policy choices depending on the specification. Several papers find managerial stock option ownership to be negatively related to risk management or positively related to firm risk (e.g., Tufano, 1996; Schrand and Unal, 1998; Cohen et al., 2000). Gormley et al. (2011) present evidence that among firms exposed to an increase in litigation risk, delta (vega) is associated with reduced (increased) subsequent risk-taking. In contrast, Brick et al. (2010) find that delta and vega are negatively associated with equity risk after including lagged dependent variables in their specifications, which we also do but other related studies do not. They argue that controlling for lagged values of dependent variables reduces omitted variable bias. They attribute their findings regarding delta and vega to risk-averse CEOs reducing risks to minimize the impact of the fluctuation of stock prices on their portfolio wealth.

Turning to the interactions of GP with vega and with delta, our expectation was that both interactions would be positively associated with risk-taking. The rationale was that if GPs partially compensate CEOs against personal losses in the event of particular bad outcomes (i.e., takeovers), then the presence of a GP should make a CEO more willing to take on greater risks as vega and delta increase. Contrary to expectations, our results show that the interaction terms are strongly and negatively related to risk-taking, especially for the interactions with delta. Once the interaction terms are included, GP is consistently associated with greater risk-taking, in accordance with the initial intuition described above. In addition, the relationships between both vega and delta and risk-taking become weaker with the inclusion of the interaction terms.

There being no existing theoretical literature concerning GPs, managerial compensation incentives, and risk-taking, we posit two possible explanations for the interaction term results. In the "takeover probability hypothesis," the salient effect of a GP is an associated higher 
probability that the firm will be the target of a takeover. ${ }^{8}$ As discussed above, when the probability of a takeover is high, there is a divergence between the CEO's incentives as an undiversified equity owner (a takeover is likely to increase equity value) and as a manager (a takeover is likely to result in job loss, implying a loss of both future compensation and professional reputation). For a CEO with high values of vega and delta, whose wealth is highly sensitive to stock price changes, the incentives as an equity owner are likely to take priority. Such a CEO may be expected to take fewer risks, as risky strategies or ventures that go badly could jeopardize her portfolio wealth as well as her potential takeover premium wealth gains, either through lowering the takeover offer that the firm might receive or, if the firm's future performance is irreversibly harmed as a result of the risks taken, through diminishing the attractiveness of the firm as a takeover target. ${ }^{9}$ For a CEO with low values of vega and delta, the desire to retain her job is more likely to dominate equity value concerns. Such a CEO may be expected to take greater risks in the hopes that a favorable risk outcome will position the firm to stave off takeover attempts. If the likelihood of job loss is already high due to high takeover probability, then a CEO with relatively low equity ownership may have little to lose from an unfavorable risk outcome that causes further deterioration in firm performance, but have much to gain if a favorable risk outcome results in retaining firm independence and the CEO's job. If takeover probability is low, then any conflict between the CEO's incentives is minimized - good firm performance increases both the CEO's wealth and the security of her position - so the relative strength of the incentives takes on much lesser importance. In this takeover probability

\footnotetext{
${ }^{8}$ This hypothesis does not rely on a particular direction of causality between GPs and takeover probability. A GP could cause an increase in takeover probability by reducing CEO resistance to a takeover, or a firm's board could adopt a GP to improve the CEO's bargaining position if the board perceives a high probability of a takeover attempt. Alternatively, some unidentified third factor could drive both GPs and takeover probability.

${ }^{9}$ Note that this argument does not necessarily imply that shareholders would want to reduce risk-taking under this scenario. Due to their more diversified portfolios, shareholders are generally less risk-averse compared to the CEO, and hence may still prefer managerial risk-taking when the takeover probability is high.
} 
hypothesis, the presence of a GP indicates higher takeover probability, vega and delta indicate the relative importance of a CEO's divergent owner versus manager incentives when takeover probability is high, and the interactions of GP with vega and with delta are negative.

The second proposed explanation for the interaction term results takes the presence of a GP as an indicator of CEO entrenchment. A GP might facilitate entrenchment by insulating a CEO from the discipline of the market for corporate control, or it could have little direct effect on entrenchment, but rather be an indicator of CEO entrenchment by other means. Gompers et al. (2003) calculate correlations between GPs and twenty-one other firm-level governance provisions that enhance the power of CEOs and boards relative to shareholders, and find ten statistically significant positive correlations and only one negative one. Bebchuk et al. (2010) document that GPs are positively associated with takeover defenses including classified boards and poison pills, and that firms with GPs have greater numbers of other provisions included in the G-index from Gompers et al. (2003) and the E-index from Bebchuk et al. (2009). Entrenchment provides greater scope for CEOs to pursue private benefits at the expense of shareholder interests, which implies that, relative to a non-entrenched CEO, an entrenched CEO may have more at stake with regard to risk-taking. The negative relationship between risk-taking and both delta and vega in our initial results is consistent with a risk-averse CEO responding to greater compensation incentives by reducing risks to lower the probability of CEO wealth losses. If risk-taking jeopardizes a CEO's private benefits as well as the value of her equity holdings, then an entrenched CEO, who likely has greater private benefits than a non-entrenched CEO, will have a greater incentive to reduce risk-taking in response to higher vega and delta. In this entrenchment hypothesis, the presence of a GP indicates greater entrenchment, and the negative 
interactions of GP with vega and with delta reflect an entrenched CEO's greater propensity to reduce risk-taking due to her greater scope for private benefits.

We first attempt to distinguish between these two hypotheses by examining the relationship between GP and takeover probability, as well as decomposing GP into a component associated with takeover probability and a component unrelated to takeover probability. The second component incorporates entrenchment effects associated with the presence of a GP as well as any other non-takeover-related effects. Consistent with our takeover probability hypothesis, the interactions of the takeover-related component with delta and, to a lesser degree, with vega have similar signs and significance as the interactions of GP with delta and with vega. The interactions of the non-takeover-related component with vega are negative in some models, but those with delta are never significant. This suggests that our results concerning GP, compensation incentives (especially delta), and risk-taking are primarily driven by the relationship between GP and takeover probability.

To test the entrenchment hypothesis, we split our sample based on several other indicators of CEO entrenchment (high CEO tenure, low board independence, no blockholding independent directors, no institutional blockholders, high G-index, and a composite measure of CEO power). If the entrenchment hypothesis is correct, then the negative relationships between the interactions of GP with vega and with delta should be stronger in the sub-samples with greater CEO entrenchment. However, our results suggest that the interaction terms are not statistically different from each other across the sub-samples.

We also replace GP with the estimated overall takeover probability of a firm and find results with a similar pattern to our main results but with less statistical significance. Takeover probability is positively related to managerial risk-taking, the interaction of takeover probability 
with delta is only weakly negatively related to risk-taking, and the interaction of takeover probability with vega is not significantly related to risk-taking. These results are, to the best of our knowledge, the first empirical findings concerning takeover probability and managerial risktaking. Taken with our previous findings, these results suggest that although the channel through which GP affects risk-taking is takeover probability, not all contributors to a firm's takeover probability affect risk-taking in the same way.

This paper presents findings related to multiple questions that have not previously been investigated. We aim to contribute to the literature intersecting corporate governance, executive compensation, and managerial risk-taking. This is the first paper to empirically establish a positive relationship between GPs and risk-taking, one that is revealed only by controlling for the negative interactive effects on risk-taking of GPs with compensation incentives. Our finding that the relationship between compensation incentives and risk-taking is highly dependent on crosssectional variation in GPs may explain why previous research on vega, delta, and risk-taking have yielded mixed empirical results. We find no evidence that the importance of GPs with respect to managerial risk-taking is based on CEO entrenchment. Rather, GPs' importance appears to be based on their positive association with takeover probability, and the divergence of a CEO's incentives in the shadow of takeover threats. Although the market for corporate control has been proposed as a means to reduce agency costs arising from the separation of ownership from control (e.g., Manne, 1965; Fama, 1980), our evidence suggests that, although diversified shareholders prefer risk-taking (Jensen and Meckling, 1976), an active takeover market may discourage a risk-averse manager from undertaking risks in the face of compensation incentives. Because risk-taking should also affect firm valuation, the implications of the complexity of the interaction of these and possibly other governance mechanisms are general. 
The structure of the remainder of this paper is as follows. Section 2 describes the data and the variables used in the empirical analysis, and reports the summary statistics. Section 3 presents the empirical results. Section 4 conducts robustness checks to substantiate our major findings, and Section 5 concludes.

\section{Sample, Variables, and Summary Statistics}

\subsection{Data and Sample}

Our sample is an intersection of several databases. Data for GPs and other provisions of the G-index (Gompers et al., 2003) are obtained from RiskMetrics (formerly IRRC), which mainly covers S\&P 1,500 firms. The data are available as of the first day of September 1990, July 1993, July 1995, February 1998, February 2000, February 2002, January 2004, and January 2006. Because not every year's data is covered, we follow the convention in the literature (e.g., Gompers et al., 2003) and assume that a firm's data for a year not covered by the database are the same as those in the previous year. This is reasonable as governance provisions generally change slowly over time. In order to merge the RiskMetrics data with the financial data from COMPUSTAT, starting in 1998 we convert year t in RiskMetrics to year t-1. ${ }^{10}$

Our risk-taking variables are calculated using CRSP daily and COMPUSTAT quarterly databases. The compensation data are from EXECUCOMP, from which vega and delta are estimated. Because the coverage of EXECUCOMP starts at 1992, our sample also starts at 1992. Data on CEO characteristics such as tenure and age are also obtained from EXECUCOMP. The risk-free interest rates in the estimation of vega and delta are the yields-to-maturity of constantmaturity Treasury bonds, which are obtained from Federal Reserve H15 Report. The target firm

\footnotetext{
${ }^{10}$ COMPUSTAT sets a year to be $t$ if the ending month of a fiscal year is between June of year $t$ and May of year $\mathrm{t}+1$. Starting in 1998, the RiskMetrics data are available at either January or February of a specific year, which would correspond to the previous year following the convention in COMPUSTAT.
} 
data used to test the association between GPs and takeover probability are obtained from Thomson One Banker.

We delete firms with dual-class stocks from our sample because the special voting structure of these firms may imply a very different role for other governance mechanisms. Consistent with the convention in the literature, we also delete finance (one-digit SIC code equals 6) and utility (two-digit SIC code equals 49) firms due to the highly regulated nature of those industries.

After merging the relevant data sets, our primary sample to examine the risk-taking effects of GPs includes 8,199 firm-year observations from 1992 to 2006, and 1,543 unique firms. ${ }^{11}$ Our primary sample to test the relation between GPs and takeover probability has 10,873 firm-year observations. Due to the restrictions of the RiskMetrics and EXECUCOMP databases, our samples mainly cover the S\&P 1,500 firms.

\subsection{Variables}

We describe the major variables used in our empirical analysis in this subsection. The discussion is classified on the two types of regression models: risk-taking and takeover probability. For space concerns, the description is cursory. The detailed definition for each variable is listed in the Appendix.

Our GP measure is a dummy variable that equals one if the firm has a GP for its CEO, and zero otherwise. As mentioned previously, governance provisions in the components of the Gindex often cluster. Therefore, we also control for a Net G-index, defined as the G-index net of GP, throughout our analysis. ${ }^{12}$

\subsubsection{Risk-taking}

\footnotetext{
${ }^{11}$ There are some small variations of sample sizes depending on the specific risk-taking variables, due to the availability of observations. The sample size reported here refers to the sample size with respect to the volatility of stock returns.

${ }^{12}$ The G-index includes GP as one of its components.
} 
We consider the volatilities of both stock returns and earnings as our risk-taking variables. Our first risk-taking variable is the standard deviation of daily stock returns over the fiscal year (Volat_stk), following the convention in the literature (e.g., Coles et al., 2006; Brick et al., 2010). We also estimate the idiosyncratic risk as the standard deviation of the residuals from the market model on daily stock returns over the fiscal year (Idio_stk). ${ }^{13}$ In contrast to most related studies on risk-taking but similar to John et al. (2008), we also calculate the volatility of earnings, both as the volatility of return on assets (ROA) and the volatility of return on equity (ROE). Unlike stock returns which have daily observations, however, earnings data are only available quarterly. To increase the number of observations for the calculation of the volatilities, we estimate the standard deviations of ROA and ROE over the past 20 quarters, including current year's quarters. This may raise the concern of endogeneity, since most observations used in the calculation of the standard deviations occur before current year. However, in all our empirical specifications on risk-taking, we include lagged dependent variables as controls. We further address endogeneity in the robustness checks. We use the logs of all of the risk-taking variables because they typically have skewed distributions.

We employ the one-year approximation (OA) method as in Core and Guay (2002) to estimate the CEO pay-performance sensitivity (delta) and the sensitivity of CEO wealth to stock return volatility (vega). Delta is defined as the sensitivity of CEO wealth to a $1 \%$ change in stock price. Vega is the sensitivity of CEO wealth to a 0.01 change in the standard deviation of stock returns. A precise estimate of these two sensitivities requires a complete knowledge of the option grants and exercising by CEOs over the years, and therefore poses an extremely high demand for data. Fortunately, Core and Guay (2002) show that using the information that is available in the

\footnotetext{
${ }^{13}$ Our results are similar if we calculate the idiosyncratic volatility based on Fama-French three-factor model (Fama and French, 1992) or Fama-French-Carhart four-factor model (Carhart, 1997).
} 
current proxy statement only, one could obtain estimates of the two sensitivities with high precision. ${ }^{14}$ Many follow-up studies on CEO compensation utilize their OA method to estimate delta and vega (e.g., Coles et al., 2006; Brick et al., 2010; Chava and Purnanandam, 2010; Brown et al., 2011; Cadman et al., 2011). Guay (1999) shows that option vega is several orders of magnitude higher than stock vega. Therefore, we follow other studies and use the option vega to approximate the vega of CEO total wealth (e.g., Knopf et al., 2002; Rajgopal and Shevlin, 2002; Coles et al., 2006). Similar to many others, we use the annualized standard deviation of monthly stock returns over the past five years as the stock return volatility in the estimation of delta and vega (e.g., Brick et al., 2010). ${ }^{15}$ We use the average dividend yield of the past three years as provided by EXECUCOMP as the dividend yield. Finally, the risk-free rate is approximated by the yield-to-maturity of the constant-maturity Treasury bonds matched by the closest maturity. ${ }^{16}$ Because vega and delta typically have skewed distributions, we take the logs of both variables.

The control variables in the risk-taking regressions are based on a survey of previous literature. They include $\mathrm{CEO}$ tenure, $\mathrm{CEO}$ age, $\mathrm{CEO}$ cash compensation, operating income, firm size, market-to-book ratio, sales growth rate, capital expenditure, R\&D expense, leverage, the number of business segments, and firm age (Coles et al., 2006; John et al., 2008; Brick et al., 2010; Brown et al., 2011; Cadman et al., 2011). Brick et al. (2010) show that it is critical to control for the lagged dependent variables to alleviate the omitted variable bias that may plague the empirical relations between delta and vega and managerial risk-taking. Therefore, throughout the risk-taking models we control for the lagged dependent variables, distinguishing our study

\footnotetext{
${ }^{14}$ They show that the estimates based on the OA method capture on average more than $99 \%$ of the variations of the actual sensitivities.

${ }^{15}$ This is also the volatility measure provided by EXECUCOMP in the estimation of Black-Scholes option value.

${ }^{16}$ Our results are not qualitatively changed if we give the options a simple "haircut" by assuming that the maturity of all options is $70 \%$ of the stated maturity. This is the method used by EXECUCOMP and some related studies (e.g., Brick et al., 2010).
} 
from most related work. In all of our risk-taking regressions, we also control for two-digit SIC industry dummies and year dummies.

\subsubsection{Takeover Probability}

Similar to Billett and Xue (2007), we use data on completed takeovers, rather than takeover bids, to test the association between GPs and takeover probability. Because we are interested in the ex-ante takeover probability associated with GPs, we define a target dummy variable which equals one if the firm is a takeover target in the following year, and zero otherwise. Schwert (2000) shows that it is difficult to distinguish hostile takeovers from friendly ones empirically. Therefore, our takeover targets include both hostile and friendly takeovers, similar to other studies (Billett and Xue, 2007; Cremers et al., 2009; Bebchuk et al., 2010; Jenter and Lewellen, 2011). In addition to GP and the Net G-index, other control variables are based on the literature (Billett and Xue, 2007; Cremers et al., 2009; Bebchuk et al., 2010; Jenter and Lewellen, 2011). Specifically, the controls include CEO tenure, CEO age, stock return, operating income, market capitalization, market-to-book ratio, leverage, tangible assets, firm age, and the takeover vulnerability of the firm's industry (Industry target). ${ }^{17}$ Models that include Industry target do not include two-digit SIC industry dummies. All of the regression models control for year effects.

\subsection{Summary Statistics}

Panel A of Table 1 presents the summary statistics of the major variables used in our empirical analysis. In our sample, $66 \%$ of the firms have GPs for their CEOs. This statistic matches that in Bebchuk et al. (2010). ${ }^{18}$ The mean and median values of vega (delta) are $\$ 149,200(\$ 1,370,080)$ and $\$ 55,440(\$ 242,970)$, respectively. These statistics are slightly higher

\footnotetext{
${ }^{17}$ We also entertain sales growth rate and, similar to Bebchuk et al. (2010), a dummy variable indicating whether the firm is incorporated in Delaware and the Herfindahl index on the degree of competition of the firm's industry. These coefficients are not significant in any of the model specifications.

${ }^{18}$ Similar to Bebchuk et al. (2010), we also find that there is generally an uptrend for GPs over the years.
} 
than those reported in Coles et al. (2006) and Brick et al. (2010), probably reflecting our more recent data coverage and the generally upward trend in the awarding of options and stocks to executives over the sample years. The data also suggest that around 3\% of our sample firms are takeover targets during the sample years. The small incidence of targets is consistent with the fact that our sample firms are the largest in the U.S., and hence may be less likely to be takeover targets. The summary statistics of other variables match those reported in the literature (Coles et al., 2006; Brick et al., 2010; Cadman et al., 2011)

\section{Insert Table 1 about here}

Panel B reports the correlations among GP and other major variables. The correlation coefficient between GP and the Net G-index is 0.18 . This positive and significant correlation is consistent with the evidence in Gompers et al. (2003) that governance provisions often cluster. The statistics in Panel B also suggest that the correlations between GP and the risk-taking variables are mixed. While the correlations between GP and the two volatilities of earnings are positive, GPs are negatively correlated with the total and idiosyncratic volatilities of stock returns. Interestingly, the statistics in Panel B also show that while GP is negatively correlated with delta, it is positively correlated with vega. Because delta includes the sensitivity with respect to stock ownership but vega does not, this evidence may suggest that GP is associated with less CEO stock ownership but more CEO option holdings. ${ }^{19}$ Panel B also shows that there are high correlations among the four risk-taking variables, as expected.

\section{Empirical Results}

In this section we first examine the empirical relation between GP and risk-taking, as well as the interactive effects of GP and CEO compensation vega and delta on risk-taking. We then test

\footnotetext{
${ }^{19}$ Indeed, we find that the correlation between GP and CEO stock ownership is -0.24 and the correlation between GP and CEO total option holdings is 0.13 .
} 
two hypotheses that may explain the unexpected negative interactions of GP with vega and with delta: the takeover probability hypothesis and entrenchment hypothesis. Throughout our analysis, the standard errors are adjusted for heteroskedasticity (White, 1980) and clustered at the firm level to control for auto-correlations (Petersen, 2009).

\subsection{Golden Parachutes and Risk-taking}

Intuition suggests that because a GP provides a form of insurance for a CEO in case her firm becomes the target of a takeover if the CEO pursues risky corporate strategies, the provision of GPs should encourage risk-taking. Indeed, recent studies on CEO severance contracts document that severance payments encourage CEO risk-taking (Ju et al., 2003; Brown et al., 2011; Cadman et al., 2011; Huang, 2011). Therefore, we expect that GP is positively associated with managerial risk-taking. We test the association between GP and the four proxies for risk-taking described in subsection 2.2.1. The results are reported in Table 2. We use lagged values of the risk-taking variables to address endogeneity. Fixed effects (FE) models are frequently used to alleviate endogeneity concerns by controlling for any time-invariant firm-specific characteristics. However, in governance studies in general and our analysis in particular, the small time-series variation of the governance variables may render FE models ineffective (Zhou, 2001). ${ }^{20}$ Therefore, in our primary empirical analysis we rely on pooled panel regressions, although we check the robustness of our results using FE models.

Table 2 shows that GP is not significantly associated with any of the risk-taking variables, though the coefficients on GP are positive as predicted. These results are not consistent with the prediction that GPs encourage risk-taking. The insignificant association between GP and risktaking contrasts with the consensus finding that severance contracts encourage managerial risk-

\footnotetext{
${ }^{20}$ In our sample of 8,199 firm-year observations, only 916 (11.2\%) experienced changes in GPs.
} 
taking. This suggests that the mechanism through which GPs affect managerial incentives may be quite different from that of severance contracts.

The results in Table 2 also show that the Net G-index is negative and significantly associated with risk-taking throughout the models. In unreported analysis, we also show that similar results obtain for the G-index. ${ }^{21}$ Therefore, though our results confirm the findings in John et al. (2008) that managerial entrenchment as proxied by the G-index discourages managers from risk-taking, our results also suggest that the individual provisions of the G-index may have very different effects on risk-taking.

\section{Insert Table 2 about here}

Consistent with Brick et al. (2010), the results in Table 2 show that both vega and delta are negatively associated risk-taking, and except for the coefficients on vega for the models with the volatilities of earnings, the coefficients are all significant. Therefore, our results suggest that the sensitivities of CEO wealth to both stock price and stock return volatility discourage CEO risktaking. The results with respect to delta are relatively easy to understand, because they accord with the argument that risk-averse CEOs reduce risk-taking to avoid portfolio wealth losses. The risk-reducing effect of vega, however, is harder to explain, because a higher vega suggests that a CEO's option value is more sensitive to firm risk, and therefore the CEO is expected to take more risks. ${ }^{22}$ But as Hjortshoj (2007) demonstrates, the sensitivity of option value to volatility may not be equivalent to the sensitivity of the certainty equivalent of option cash flows to volatility, especially for an undiversified CEO with sufficient in-the-money options. A higher vega may imply a reduced certainty equivalent of option cash flows in response to an increase in volatility, and so discourages CEO risk-taking. In summary, the negative associations between

\footnotetext{
${ }^{21}$ The results are significant for the first three models, and weakly significant at the $11 \%$ level for the fourth one.

${ }^{22}$ Indeed, most studies on executive compensation also find a positive association between vega and managerial risk-taking (e.g., Coles et al., 2006; Low, 2009; Gormley et al., 2011).
} 
vega and delta and risk-taking in Table 2 suggest that managerial incentive compensation may have the perverse effect of discouraging a risk-averse manager from taking risks.

The control variables generally have their expected signs. The results are consistent with some papers but not others. For example, while both Brick et al. (2010) and we document a positive association between market-to-book ratio and managerial risk-taking, Coles et al. (2006) find a negative relation between this variable and equity volatility. The same is true for capital expenditure. Table 2 also shows that some of the control variables have opposite effects on the volatility of stock returns as compared to the volatility of earnings (e.g., CEO tenure, sales growth rate, and firm age), which suggests that some firm and CEO charactertics may have divergent effects on the volatility of cash flows and the volatility of the cost of capital. ${ }^{23}$ Consistent with the serial dependency of the risk-taking proxies, all the lagged dependent variables are positive and highly significant.

\subsection{Interaction of Vega and Delta and Golden Parachutes on Risk-taking}

Despite the insignificant effect of GP and the negative effects of vega and delta on risk-taking as shown in Table 2, intuition suggests that a CEO with a GP would be less averse to taking risks when faced with compensation incentives, since such a CEO is insured against the downside of risk-taking to some extent but could still enjoy the upside as her wealth is tied to the fluctuation of stock prices. This intuition would predict that the interaction of GP with vega and with delta should be positively associated with risk-taking. We test this prediction in this subsection. The models are the same as in Table 2, with two additional interaction terms: the products of GP with vega and with delta. The results are presented in Table 3.

Insert Table 3 about here

\footnotetext{
${ }^{23}$ Stock price is the discounted value of all future cash flows, and earnings are only related to the cash flow of a single period. Therefore, the volatility of stock returns reflects both the variability of the discount rate as well as the variability of cash flows, while the volatility of earnings reflects only the latter.
} 
Surprisingly, the coefficients on the two interaction terms are opposite to expectations. The interaction of GP with vega is either negatively or insignificantly associated with volatilities; the interaction of GP with delta is negatively associated with all four risk-taking measures. Therefore, the results in this table suggest that rather than increasing the incentive of a CEO to take risks, the combination of a GP and managerial wealth sensitivities has the perverse effect of decreasing the risk-taking incentive of the CEO.

Interestingly, once the two interaction terms are controlled for, GP is positively and highly significantly associated with all four risk-taking variables, as the common intuition suggests. The interaction results suggest that while GPs may increase risk-taking when vega and delta are low, GPs decrease risk-taking when the two sensitivities are high. However, a concern for the interaction results is that because GP and vega and delta are all significantly correlated as shown in Panel B of Table 1, the relations we documented in Table 3 may be spurious. To solve this issue, in an untabulated analysis we run regressions using the models in Table 2 on sub-samples characterized by different levels of vega and delta. To highlight the difference between the coefficients across sub-samples, we compare the impacts of golden parachutes on risk-taking for firms with vega (delta) above the third quartile and firms with vega (delta) at or below the first quartile. In the sub-samples split by delta, GP is positively and significantly associated with all four risk-taking variables for firms with low CEO delta but is not significantly associated with risk-taking when delta is high. Further, Chow tests indicate that the GP coefficients across the sub-samples are statistically different. In the sub-samples split by vega, the coefficients on GP are higher in the low vega sub-sample, consistent with the interaction results in Table 3, but they are not statistically different from the coefficients on GP in the high vega sub-sample. Although the sub-sample results are not as strong as the interaction results, the basic implication remains 
intact, especially with respect to a differential effect of GPs on risk-taking based on the levels of delta.

The results in Table 3 also show that after netting out the interactive effects of GP with vega and with delta, the effects of vega and delta on risk-taking become either weaker or insignificant. ${ }^{24}$

\subsection{Takeover Probability Hypothesis}

The intuition for the positive interactions of GP with vega and delta on risk-taking rests on a GP being similar to a conventional severance contract, which compensates a departing CEO for her job loss. One possible channel through which the interactions of GP with vega and delta may decrease managerial risk-taking, which is absent from the conventional severance contract, is the potential association between GP and the takeover probability of a firm. Such association is expected because GPs are only effective under a change-in-control scenario, but the direction of this association is ambiguous. On the one hand, if a GP increases the cost of a takeover and hence serves as an effective antitakeover device, then a GP may reduce the attractiveness of a firm as a takeover target and so increase the entrenchment of the CEO by deterring hostile takeovers. ${ }^{25}$ As argued above, an entrenched CEO may be more averse to risk-taking with an increase of incentive compensation, which would generate negative interactions of GP with vega and delta on risk-taking. Note that this entrenchment hypothesis does not depend on the antitakeover effect of GPs, though such an effect could bring CEO entrenchment. A GP may simply signal CEO entrenchment without actually entrenching the CEO, especially given

\footnotetext{
${ }^{24}$ An interesting topic for future study is how the relative magnitudes of a CEO's equity portfolio, expected future compensation, and potential GP payments influence managerial risk-taking. Data for GP payment magnitude are not readily available in database format, and so this topic is beyond the scope of this paper.

${ }^{25}$ This is implicitly assumed by many studies which use the G-index or the E-index as an antitakeover proxy, since GP is a component of these indexes (e.g., Klock et al., 2005; Chava et al., 2009; Cremers et al., 2009; Chemmanur et al., 2010; Straska and Waller, 2010).
} 
findings in the literature of positive correlations between GP and other antitakeover provisions which may entrench a CEO (Gompers et al., 2003; Bebchuk et al., 2010).

On the other hand, GPs could reduce CEOs' resistance to takeovers, hence increasing the incentive of a potential acquirer to take over a firm (Lambert and Larcker, 1985; Jensen, 1988; Ferreira et al., 2011). This effect implies a positive association between GP and the likelihood of a firm as a takeover target. A higher takeover probability may increase the divergence of the incentives of a $\mathrm{CEO}$ as an equity owner and as a manager, because the price premiums that are often associated with takeovers imply a wealth gain for a $\mathrm{CEO}$ with substantial equity and option holdings, but at the same time imply a loss of both future compensation and professional reputation. As argued above, such incentive divergence may generate the negative interactions of GP with vega and with delta on CEO risk-taking. We examine this takeover probability hypothesis in this subsection, and the entrenchment hypothesis in the next subsection. Because the entrenchment hypothesis does not depend on the antitakeover effect of GPs, the takeover probability hypothesis and the entrenchment hypothesis may not be mutually exclusive.

Given that the effect of GP on the takeover probability of the firm is theoretically ambiguous, we test their association empirically using probit regressions on the target dummy defined previously. We entertain three model specifications to check the robustness of our findings. In the first model, we control for the industry effects but do not adjust the control variables based on their industry median values. In the second model, we do not include the industry controls but industry-adjust stock return, operating income, and leverage, following Billett and Xue (2007) and Jenter and Lewellen (2011). Finally, in the third model, we follow Cremers et al. (2009) and Bebchuk et al. (2010) and industry-adjust more control variables, including market capitalization and PPE. The results are reported in Table 4. 
The three models in Table 4 document a consistently positive and significant association between GP and takeover probability, which is consistent with the results reported in Bebchuk et al. (2010). The coefficients are also similar across the models. Therefore, our results are consistent with the argument that GPs may reduce the resistance of CEOs to takeovers, and increase the probability of the firm as a takeover target. Our results are not consistent with the argument that because GPs increase the cost to the acquirer, GPs may help to deter hostile takeovers and entrench CEOs. But as argued previously, the presence of a GP may signal managerial entrenchment without entrenching the manager. Therefore, the results in Table 4 by themselves cannot rule out the entrenchment hypothesis.

Insert Table 4 about here

Table 4 also shows that stock return, operating income, CEO tenure, market-to-book ratio, firm age, and the industry target dummy are all significantly related to takeover probability, and the coefficients are consistent with the prior literature (Billett and Xue, 2007; Cremers et al., 2009; Bebchuk et al., 2010; Jenter and Lewellen, 2011). However, other control variables are not significant. In particular, the Net G-index is not significantly associated with takeover likelihood, which suggests that many provisions of the G-index or the E-index may not be takeover-related, despite the wide usage of these indexes as an antitakeover proxy. ${ }^{26}$

We next test the takeover probability hypothesis, which is built on the takeover-facilitating effect of GP as established in Table 4. To calculate takeover probability we use the predicted values from Model 3 of Table 4, but the results are similar using other models. We first calculate the marginal probability of takeovers associated with GP. We then decompose GP into two parts

\footnotetext{
${ }^{26}$ In unreported analysis, we obtain similar results by replacing the Net G-index with a Net E-index (E-index minus GP). We also find that the G-index and the E-index are not significantly related to takeover probability. Bradley and Chen (2011) show that out of the individual components of the G-index, only GP and classified boards are significantly associated with takeover probability.
} 
using a linear regression of GP on this marginal probability and a constant term. The predicted value of this regression is the component of GP that is related to takeover probability (Mp_gp). ${ }^{27}$ The residual of this regression orthogonal to $\mathrm{Mp} \_g p$ is the non-takeover-related component of GP (Rs_gp), which incorporates any entrenchment effects and other non-takeover-related effects associated with the presence of a GP. We then control for Mp_gp in the Models of Table 2 and interact Mp_gp with vega and with delta. Our takeover probability hypothesis predicts that the interactions of Mp_gp with vega and delta are negatively associated with risk-taking, and Mp_gp is positively associated with risk-taking, similar to the patterns using GP and its interactions with vega and delta as established in Table 3. We report the results in Panel A of Table 5. The results support the takeover probability hypothesis, especially for the results involving the interactions of Mp_gp with delta: all four interaction terms are negative and highly significant at the $1 \%$ level; and Mp_gp is positive and highly significant once the interaction terms are included. The positive and significant coefficient on Mp_gp accords with the takeover probability hypothesis because it predicts that if the delta (vega) of CEO wealth is low, a higher takeover probability is likely to increase the risk-taking incentive of the CEO, because the upside of risk-taking may stave off potential takeover attempts; at the same time, the CEO has little to lose from the downside of risk-taking as her delta (vega) is low. Though the interaction results with respect to vega are less pronounced as Mp_gp * Vega is only significant in Model 1, it is also weakly significant at the $11 \%$ level in Model 2. Interestingly, once Mp_gp is included, GP either loses significance or becomes negative and significant. This result suggests that the positive effect of GP on risk-taking as we documented in Table 3 is driven by the takeover-related component of

\footnotetext{
${ }^{27}$ Directly using the marginal probability of takeovers associated with GP would produce similar results as using this linearly-transformed takeover-related component of GP.
} 
GP, which is consistent with our takeover-probability hypothesis. ${ }^{28}$ Overall, the results in Panel A provide support to the takeover-probability hypothesis.

\section{Insert Table 5 about here}

A concern for the above results is that if Mp_gp and GP are highly correlated with each other, then the effect of GP on risk-taking, including the interaction effects, may be mechanically driven by Mp_gp. We find that the correlation between Mp_gp and GP is 0.70, but we also find that the correlation between the non-takeover-related component of GP (Rs_gp) and GP is 0.71 . If the effect of Mp_gp on risk-taking is due to its high correlation with GP, then similar results should be observed for Rs_gp. We examine this argument in Panel B. The models are similar to those in Panel A, except that we replace Mp_gp with Rs_gp. The interactions of Rs_gp with vega are similar to the interactions of Mp_gp with vega, as the argument predicts. However, the direct effect of Rs_gp on risk-taking is not positive and significant (it is in fact negative and significant in the last two models), and more importantly, the interactions of Rs_gp with delta are never significant. GP (Delta) continues to be positive (negative) and significant. Therefore, the results in Panel B are not consistent with the argument that the relation between the takeover-related component of GP and risk-taking is driven by its high correlation with GP. Our takeoverprobability hypothesis appears to provide a more satisfactory explanation for the results. ${ }^{29}$

In an undocumented analysis, we check the robustness of the results by running regressions for the models in Table 2 but conditional on sub-samples characterized by different levels of

\footnotetext{
${ }^{28}$ Replacing GP with the non-takeover-related component of GP (Rs_gp) produces similar results. The results are also similar when we drop GP from the regression models.

${ }^{29}$ In an untabulated analysis we also check the robustness of the results by including both Mp_gp and Rs_gp, and their interactions with vega and with delta in the risk-taking models. The results show that the interaction of Mp_gp with delta is negative and significant, and $\mathrm{Mp} \_g p$ is positive and significant in all four models. The interaction of Mp_gp with vega is negative but insignificant. The interaction of Rs_gp and vega is negative and weakly significant in the first two models, but Rs_gp is negative and insignificant in all four models. In addition, the interaction of Rs_gp with delta is positive and insignificant in all four models. Therefore, these results with many interaction terms, though potentially suffering from the concerns of multicollinearity and spurious correlations, are still largely consistent with the results in Table 5.
} 
vega and delta, similar to the robustness check we did for the results in Table 3 . To test our takeover-probability hypothesis, we replace GP with its takeover-related component and the nontakeover-related component. ${ }^{30}$ This hypothesis predicts a more positive effect of Mp_gp on risktaking when the level of vega or delta is low. To highlight the differential impact of Mp_gp on risk-taking conditional on different levels of vega and delta, we run regressions on the subsample with vega (delta) being above its third quartile, and the sub-sample with vega (delta) being at or below its first quartile. Similar to the sub-sample results on GP and risk-taking with respect to vega, we do not detect statistical differences between the coefficients on Mp_gp across sub-samples characterized by different levels of vega. However, our results show that while Mp_gp (Rs_gp) is negatively (positively) associated with risk-taking when delta is high, it is positively and significantly associated with risk-taking when delta is low. The negative association between Mp_gp and risk-taking is significant for the two volatilities of earnings. The Chow tests also indicate statistical differences between the coefficients on Mp_gp across the four pairs of sub-samples. The negative effect of Mp_gp on risk-taking when delta is high accords with our takeover-probability hypothesis and, together with the positive effect of Rs_gp on risktaking when delta is high, provides an explanation for the insignificant association between GP and risk-taking for high-delta firms as discussed above.

\section{Insert Table 6 about here}

To further examine the takeover probability hypothesis, we test whether the interactions of the total probability of the firm as a takeover target (Tp) with vega and delta on risk-taking are similar to the interactions of GP with vega and delta on risk-taking. The results are presented in Table 6. Although the signs of the interaction terms in Table 6 are similar to those in Table 3 as the takeover probability hypothesis predicts, only the interaction of Tp with delta in Models 1

\footnotetext{
${ }^{30}$ The results are similar if we simply add the takeover-related component of GP as an additional control variable.
} 
and 4 is significant. Consistent with the takeover probability hypothesis, after controlling for the interaction terms, $\mathrm{Tp}$ is positive and significant throughout the four models. Taken together, the results in Tables 5 and 6 suggest that although the primary channel through which a GP affects risk-taking is takeover probability, not all contributors to a firm's takeover probability affect risk-taking in the same way. ${ }^{31}$

\subsection{Entrenchment Hypothesis}

Given that any effects of a GP related to CEO entrenchment should be incorporated into the non-takeover-related component of GP, the results of Table 5 indirectly contrast the predictions of the takeover probability and entrenchment hypotheses. However, a more direct implication of the entrenchment hypothesis is that the negative interactions of GP with vega and with delta should be more pronounced for a CEO who may be entrenched by other means besides a GP. We examine this implication in this subsection.

We entertain several proxies of CEO entrenchment based on the literature. First, longer CEO tenure may indicate greater entrenchment (Morck et al., 1988; Berger et al., 1997; Hermalin and Weisbach, 1998; Ryan and Wiggins, 2004). A higher percentage of independent directors is generally associated with better monitoring, including higher turnover-performance sensitivity of a CEO, and hence may lower CEO entrenchment (see, e.g., the evidence as surveyed in Hermalin and Weisbach, 2003). We use the percentage of non-independent directors so that a higher value suggests greater entrenchment. Agrawal and Nasser (2011) show that an independent director

\footnotetext{
${ }^{31}$ One plausible and special feature of GP as compared with other contributors to takeover probability is that a GP may most directly signal a CEO's willingness to accept a takeover offer, while many other contributors relate to firm characteristics rather than CEO characteristics. Therefore, a CEO may regard the higher takeover probability associated with the presence of a GP to be different compared to other contributors to takeover probability, thereby generating the differential effects of the marginal probability of takeovers associated with GP and other contributors to takeover probability.
} 
who also holds a block of shares has both a strong incentive and the ability to monitor a CEO. ${ }^{32}$

We define a dummy variable to equal one if the firm does not have an independent blockholder with at least 5\% ownership, and zero otherwise. The literature also suggests that other blockholders have strong incentives to incur monitoring costs and reduce entrenchment (Shleifer and Vishny, 1986; Agrawal and Mandelker, 1990; Bertrand and Mullainathan, 2001). We define a dummy variable to equal one if the firm does not have an institutional blockholder with at least $5 \%$ ownership, and zero otherwise. ${ }^{33}$ In addition, provisions besides GP in the G-index such as classified boards and poison pills may entrench a CEO. We expect that a higher Net G-index should be associated with higher entrenchment. We also consider a combination of entrenchment mechanisms and define a CEO power dummy similar to Moeller (2005), which equals one if the CEO ownership and non-independent directors are above their respective sample medians, the CEO is also the chairman, and the tenure of the CEO is at least five years, and zero otherwise. ${ }^{34}$

To test the entrenchment hypothesis, we create dummy variables based on the continuous variables indicating $\mathrm{CEO}$ entrenchment (CEO tenure, fraction of non-independent directors, and the Net G-index), that equal one if the values of their corresponding continuous variables are above their respective sample medians, and zero otherwise. ${ }^{35,36}$ We test the entrenchment

\footnotetext{
${ }^{32}$ Specifically, they show that independent blockholders are associated with lower levels of CEO compensation, higher wealth-performance sensitivities, and higher turnover-performance sensitivities.

${ }^{33}$ The data for independent directors and the block ownership of independent directors are obtained from RiskMetrics. The data for institutional ownership is obtained from Thomson Reuters.

${ }^{34}$ This definition of the CEO power dummy selects around $17 \%$ of the sample firms with high CEO entrenchment, which is similar to the fraction in Moeller (2005).

${ }^{35} \mathrm{We}$ do not create a dummy variable for boards with a majority of independent directors as our sample covers the largest firms in the U.S., many of which have a majority of independent directors (see, e.g., the evidence in Chhaochharia and Grinstein, 2009). This could be due either to shareholder activism which was initiated in the mid1980s, or to new regulations such as Sarbanes-Oxley Act of 2002. Having an externally-imposed majority of independent directors may not indicate the differential governance quality of firms. We check the robustness of our results by running regressions conditional on whether firms have a majority of independent directors, and obtain similar results.

${ }^{36}$ In unreported analysis, we find that the correlations between these six proxies of managerial entrenchment and GP are $-0.14,-0.21,0.08,-0.11,0.18$, and -0.21 , respectively. It is clear from these statistics that these proxies indicate managerial entrenchment that is distinct from possible entrenchment as proxied by GP.
} 
hypothesis by running regressions on sub-samples characterized by different degrees of CEO entrenchment as indicated by each of the six entrenchment dummies, and testing the statistical differences between the coefficients on GP * Vega and GP * Delta across the sub-samples. The entrenchment hypothesis predicts that GP * Vega and GP * Delta are more negative and significant in the sub-sample indicating higher CEO entrenchment. We report the results in Table 7, together with the p-values for the Chow tests for the statistical differences. The results show that the coefficients on GP * Vega and GP * Delta are not statistically different across any pair of the sub-samples. Therefore, our results in Table 7 provide further evidence that is inconsistent with the entrenchment hypothesis.

\section{Insert Table 7 about here}

Similar to the models in Table 7, we also use the other three risk-taking variables to examine the entrenchment hypothesis, but none of the results supports this hypothesis. The results are not reported to save space.

In another untabulated analysis, we repeat the specification in Model 1 of Table 3 after including separately each of the six entrenchment dummy variables and interacting it with the interactions of GP with vega and with delta. The entrenchment hypothesis would predict that the triple interaction terms are negative and significant. ${ }^{37}$ However, we find them to be statistically insignificant in each case.

Finally, we examine the entrenchment hypothesis by testing whether the interactions of the proxies for CEO entrenchment with vega and with delta (not interacted with GP) are also negative and significant. If the negative interactions of GP with vega and delta are because of CEO entrenchment, then the interactive effects of other indicators of CEO entrenchment with vega and delta should also be negative. In unreported analysis, however, we find that none of

\footnotetext{
${ }^{37}$ Triple interaction terms are generally difficult to interpret. We use this analysis simply as a robustness check.
} 
these interaction terms is significant except for the interaction of the low board independence dummy and vega, which is positive and significant at the $5 \%$ level. This is opposite to the prediction of the entrenchment hypothesis. ${ }^{38}$

\section{Robustness Checks}

Endogeneity is a primary concern for any governance study. Our specific context, however, with our focus on the interactive effects of GP with vega and with delta on risk-taking, as well as the interactions of the takeover-related component of GP with vega and with delta on risk-taking, should significantly alleviate the endogeneity concern. Nonetheless, completely ruling out this concern is extremely hard, and requires a vigorous theoretical modeling of the determinants of GPs, which is not available in the literature. Empirically speaking, however, one primary source of endogeneity is the possibility that omitted variables are correlated with both GP and risktaking. Our extensive controls based on previous literature should reduce this possibility, but we apply FE models in this section to further address this concern. As mentioned previously, because governance variables generally change slowly over time, using FE models risks finding an insignificant relationship between a governance variable and the dependent variable, even if a relationship exists (Zhou, 2001). To save space, we only report the FE results on testing the takeover probability hypothesis as in Panel A of Table 5. These results are presented in Table 8. In undocumented analysis, we also employ FE models to Table 3 and obtain similar results. ${ }^{39}$

Insert Table 8 about here

\footnotetext{
${ }^{38}$ In another untabulated analysis, we also entertain other indicators of CEO entrenchment. These variables include whether the CEO is also the chairman, whether the CEO is the only insider on the board, whether the CEO is an inside hire, the ownership of all institutional shareholders rather than just blockholders, and board classification. These results do not support the entrenchment hypothesis either.

${ }^{39}$ Specifically, except for GP * Vega in Model 2 and GP * Delta in Model 4, all other interaction terms are negative and significant. GP is positive and significant throughout the models.
} 
The results in Table 8 are similar qualitatively to those in Table 5, except that the interaction term Mp_gp * Vega is no longer significant, and Mp_gp * Delta is not significant in Model 4. Therefore, the results based on the FE models still provide support to the takeover probability hypothesis. ${ }^{40}$

Our volatilities of stock returns are based on daily data, following the convention in the literature. In a robustness check, we also calculate the volatilities of stock returns (both total and idiosyncratic) based on monthly data. Similar to the calculation of the volatilities of earnings, to increase the number of observations, we use five years' data to estimate the volatilities. We repeat all the analysis using these stock return volatilities. The results are even stronger. Specifically, the interaction term Mp_gp * Vega in Model 2 of Table 5 also becomes significant. The interaction of the total takeover probability with vega also becomes negative and significant in Model 2 of Table 6.

\section{Conclusion}

In this paper we examine the relationships among GPs, compensation incentives, and managerial risk-taking. While our initial analysis finds no significant relationship between GPs and risk-taking, once we include interactive effects of GPs with vega and with delta we find that GPs are positively related to risk-taking and the interaction terms are negatively related. We posit two alternative explanations for the negative relationship between the interaction terms and risk-taking. We find empirical support for the takeover probability hypothesis, in which a GP indicates a higher probability that the CEO's firm will be the target of a takeover, which results in greater divergence of the CEO's incentives as a manager and her incentives as an equity owner. Vega and delta influence the relative importance to the CEO of these conflicting incentives. We also find that the relationships among takeover probability, compensation

\footnotetext{
${ }^{40}$ Testing the entrenchment hypothesis using FE models yields results similar to the pooled panel results.
} 
incentives, and managerial risk-taking have similar patterns, albeit weaker significance, to those found with GPs, further supporting the hypothesis that the channel through which GPs affect risk-taking is via the probability of takeovers. We find no support for the entrenchment hypothesis, in which a GP indicates an entrenched CEO for whom the links between compensation incentives and risk-taking are altered by the greater scope to pursue private benefits that entrenchment allows.

To our knowledge, the relationships described above have not previously been empirically examined. As such, our findings concerning GPs and risk-taking, takeover probability and risktaking, and the associated interactive effects with delta and vega, all represent original contributions to the financial literature. Our takeover probability hypothesis illustrates how the market for corporate control may exacerbate the tension between the incentives of the $\mathrm{CEO}$ as a manager versus those of the $\mathrm{CEO}$ as an equity owner, while compensation incentives influence the balance between the divergent incentives. Finally, our finding of substantial heterogeneity in the effect of GPs on risk-taking based on compensation incentives may serve as a useful signpost in the growing body of research on the intersection of corporate governance and managerial risktaking, indicating that a simple bilateral relationship between one governance mechanism and risk-taking may mask substantial cross-sectional variation based on executive compensation or other governance characteristics. 


\section{Appendix}

\section{Table A1. Variable Definitions}

\begin{tabular}{ll}
\hline Variable & Definitions \\
\hline GP & Dummy variable that equals one if the firm has golden parachute for its CEO, and zero otherwise.
\end{tabular}

Net G-index The G-index from Gompers et al. (2003) net of GP (G-index minus GP).

Volat_stk The log of the standard deviation of daily stock returns for at least 100 days over the year.

Idio_stk The log of the standard deviation of the residuals from the market model (with a constant term) with daily returns over the year.

Volat_roa The log of the standard deviation of the quarterly returns on assets over the past five years including current year, where return on asset is defined as net income before extraordinary items scaled by total assets.

Volat_roe The log of the standard deviation of the quarterly returns on equity over the past five years including current year, where return on equity is defined as net income before extraordinary items scaled by common equity.

Vega The log of one plus the sensitivity of CEO option portfolio value to a 0.01 change in the annualized standard deviation of stock returns. The estimation follows Core and Guay (2002)'s "one-year approximation" (OA) method. Specifically, the annualized standard deviation of monthly stock returns over the past 60 months and the average dividend yield over the past three years are used as the inputs in the estimation. Risk-free rates are the yields-to-maturity of Treasury bonds matched by the closest maturities.

Delta The log of one plus the sensitivity of CEO option and stock portfolio value to a $1 \%$ change in stock price, where the estimation of the sensitivity follows Core and Guay (2002)'s OA method. Specifically, the annualized standard deviation of monthly stock returns over the past 60 months and the average dividend yield over the past three years are used as the inputs in the estimation. Risk-free rates are the yields-to-maturity of Treasury bonds matched by the closest maturities.

CEO Tenure The log of CEO tenure in years.

CEO Age The log of CEO age in years.

CEO cash The log of CEO salary plus bonus.

Operincome Operating income before depreciation scaled by total assets.

Size The log of total assets.

Mkt value The log of total market capitalization.

$\mathrm{Mb} \quad$ Market-to-book ratio.

Salesgrow The log of the ratio of current year's sales and past year's sales.

Capexp Net capital expenditure scaled by total assets, with missing values coded as zeros.

$\mathrm{Rd} \quad \mathrm{R} \& \mathrm{D}$ expenses scaled by total assets, with missing values coded as zeros.

Leverage Debt in current liabilities plus long-term debt scaled by total assets.

Segments The number of business segments.

Firm age The number of years since the firm went public.

Target Dummy variable that equals one if the firm is a takeover target in the next year.

Stock return Annual dividend-reinvested total stock return

Industry Dummy variable that equals one if the firm's industry as classified by four-digit SIC code has at least target one firm that is a takeover target in a given year, and zero otherwise.

PPE Net PPE scaled by total assets. 


\section{References}

Agrawal, A., Knoeber, C., 1998. Managerial compensation and the threat of takeover. Journal of Financial Economics 47, 219-239

Agrawal, A., Mandelker, G.N., 1990. Large shareholders and the monitoring of managers - the case of antitakeover charter amendments. Journal of Financial and Quantitative Analysis $25,143-161$

Agrawal, A., Nasser, T., 2011. Blockholders on boards and CEO compensation, turnover and firm valuation. Working Paper. University of Alabama

Almazan, A., Suarez, J., 2003. Entrenchment and severance pay in optimal governance structures. Journal of Finance 58, 519-547

Bebchuk, L., Cohen, A., Ferrell, A., 2009. What Matters in Corporate Governance? Review of Financial Studies 22, 783-827

Bebchuk, L.A., Cohen, A., Wang, C.C.Y., 2010. Golden parachutes and the wealth of shareholders. Harvard Law School Discussion Paper 683

Berger, P., Ofek, E., Yermack, D., 1997. Managerial entrenchment and capital structure decisions. Journal of Finance 52, 1411-1438

Berkovitch, E., Israel, R., Spiegel, Y., 2000. Managerial compensation and capital structure. Journal of Economics \& Management Strategy 9, 549-584

Bertrand, M., Mullainathan, S., 2001. Are CEOs rewarded for luck? The ones without principals are. Quarterly Journal of Economics 116, 901-932

Billet, M.T., Xue, H., 2007. The takeover deterrent effect of open market share repurchases. Journal of Finance 62, 1827-1850

Born, J.A., Trahan, E.A., Faria, H.J., 1993. Golden parachutes - incentive aligners, management entrenchers, or takeover bid signals. Journal of Financial Research 16, 299-308

Bradley, M., Chen, D., 2011. Corporate governance, credit conditions, and the cost of debt. Working Paper. University of Baltimore

Brick, I.E., Palmon, O., Wald, J., 2010. Too much pay-performance sensitivity. Review of Economics and Statistics forthcoming

Brown, K.R., Jha, R., Pacharn, P., 2011. CEO severance pay and risk taking in the banking industry. Working Paper. University of Waterloo

Cadman, B.D., Campbell, J.L., Klasa, S., 2011. Are ex-ante CEO severance pay contracts consistent with efficient contracting? Working Paper. University of Utah

Carhart, M., 1997. On persistence in mutual fund performance. Journal of Finance 52, 57-82

Chakraborty, A., Sheikh, S., Subramanian, N., 2007. Termination risk and managerial risk taking. Journal of Corporate Finance 13, 170-188

Chava, S., Livdan, D., Purnanandam, A., 2009. Do Shareholder Rights Affect the Cost of Bank Loans? Review of Financial Studies 22, 2973-3004

Chava, S., Purnanandam, A., 2010. CEOs versus CFOs: Incentives and corporate policies. Journal of Financial Economics 97, 263-278

Chemmanur, T., Jordan, B., Liu, M., Wu, Q., 2010. Antitakeover provisions in corporate spinoffs. Journal of Banking \& Finance 34, 813-824

Chhaochharia, V., Grinstein, Y., 2009. CEO Compensation and Board Structure. Journal of Finance 64, 231-261

Cohen, R.B., Hall, B.J., Viceira, L.M., 2000. Do executive stock options encourage risk-taking? Working Paper. Harvard University

Coles, J., Daniel, N., Naveen, L., 2006. Managerial incentives and risk-taking. Journal of 
Financial Economics 79, 431-468

Core, J., Guay, W., 2002. Estimating the value of employee stock option portfolios and their sensitivities to price and volatility. Journal of Accounting Research 40, 613-630

Cotter, J.F., Zenner, M., 1994. How managerial wealth affects the tender offer process. Journal of Financial Economics 35, 63-97

Cremers, K., Nair, V., John, K., 2009. Takeovers and the Cross-Section of Returns. Review of Financial Studies 22, 1409-1445

Falaschetti, D., 2002. Golden parachutes: credible commitments or evidence of shirking? Journal of Corporate Finance 8, 159-178

Fama, E.F., 1980. Agency problems and the theory of the firm. Journal of Political Economy 88, 288-307

Fama, E.F., French, K.R., 1992. The cross-section of expected stock returns. Journal of Finance $47,427-465$

Ferreira, D., Ornelas, E., Turner, J.L., 2011. Unbundling ownership and control. Working Paper. London School of Economics

Goldman, E., Huang, P., 2011. Contractual versus actual severance pay following CEO turnover. Working Paper. Indiana University

Gompers, P., Ishii, J., Metrick, A., 2003. Corporate governance and equity prices. Quarterly Journal of Economics 118, 107-155

Gormley, T.A., Matsa, D.A., Milbourn, T., 2011. CEO compensation and corporate risk-taking: evidence from a natural experiment. Working Paper. The Wharton School, University of Pennsylvania

Guay, W., 1999. The sensitivity of CEO wealth to equity risk: an analysis of the magnitude and determinants. Journal of Financial Economics 53, 43-71

Hall, P.L., Anderson, D.C., 1997. The effect of golden parachutes on shareholder wealth and takeover probabilities. Journal of Business Finance and Accounting 24, 445-463

Hartzell, J., Ofek, E., Yermack, D., 2004. What's in it for me? CEOs whose firms are acquired. Review of Financial Studies 17, 37-61

Hermalin, B.E., Weisbach, M.S., 1998. Endogenously chosen boards of directors and their monitoring of the CEO. American Economic Review 88, 96-118

Hermalin, B.E., Weisbach, M.S., 2003. Boards of directors as an endogenously determined institution: a survey of the economic literature. FRBNY Economic Policy Review April, 7-26

Hjortshoj, T.L., 2007. Managerial risk-shifting incentives of option-based compensation: firm risk, leverage, and moneyness. Working Paper. University of Aarhus

Huang, P., 2011. Marital prenups? A look at CEO severance agreements. Working Paper. Tulane University

Inderst, R., Mueller, H., 2010. CEO Replacement Under Private Information. Review of Financial Studies 23, 2935-2969

Jensen, M.C., 1988. Takeovers: their causes and consequences. Journal of Economic Perspectives 2, 21-48

Jensen, M.C., Meckling, W.H., 1976. Theory of the firm - managerial behavior, agency costs and ownership structure. Journal of Financial Economics 3, 305-360

Jenter, D., Lewellen, K., 2011. CEO preferences and acquisitions. Working Paper 105, Rock Center for Corporate Governance, Stanford University

John, K., Litov, L., Yeung, B., 2008. Corporate governance and risk-taking. Journal of Finance 
63, 1679-1728

Ju, N., Leland, H., Senbet, L.W., 2003. Options, option repricing and severance packages in managerial compensation: their effects on corporate investment risk. Working Paper. University of Maryland, College Park

Kempf, A., Ruenzi, S., Thiele, T., 2009. Employment risk, compensation incentives, and managerial risk taking: Evidence from the mutual fund industry. Journal of Financial Economics 92, 92-108

Klock, M., Mansi, S., Maxwell, W., 2005. Does corporate governance matter to bondholders? Journal of Financial and Quantitative Analysis 40, 693-719

Knoeber, C.R., 1986. Golden parachutes, shark repellents, and hostile tender offers. American Economic Review 76, 155-167

Knopf, J., Nam, J., Thornton, J., 2002. The volatility and price sensitivities of managerial stock option portfolios and corporate hedging. Journal of Finance 57, 801-813

Lambert, R.A., Larcker, D.F., 1985. Golden parachutes, executive decision-making, and shareholder wealth. Journal of Accounting and Economics 7, 179-203

Low, A., 2009. Managerial risk-taking behavior and equity-based compensation. Journal of Financial Economics 92, 470-490

Machlin, J.C., Choe, H., Miles, J.A., 1993. The effects of golden parachutes on takeover activity. Journal of Law \& Economics 36, 861-876

Manne, H.G., 1965. Mergers and the market for corporate control. Journal of Political Economy $73,110-120$

Moeller, T., 2005. Let's make a deal! How shareholder control impacts merger payoffs. Journal of Financial Economics 76, 167-190

Mogavero, D., Toyne, M.F., 1995. The impact of golden parachutes on Fortune 500 stock returns: a reexamination of evidence. Quarterly Journal of Business and Economics 34, 30-38

Morck, R., Shleifer, A., Vishny, R.W., 1988. Management ownership and market valuation - an empirical analysis. Journal of Financial Economics 20, 293-315

Petersen, M., 2009. Estimating Standard Errors in Finance Panel Data Sets: Comparing Approaches. Review of Financial Studies 22, 435-480

Rajgopal, S., Shevlin, T., 2002. Empirical evidence on the relation between stock option compensation and risk taking. Journal of Accounting \& Economics 33, 145-171

Rusticus, T.O., 2006. Executive severance agreements. Working Paper. Northwestern University

Ryan, H., Wiggins, R., 2004. Who is in whose pocket? Director compensation, board independence, and barriers to effective monitoring. Journal of Financial Economics 73, 497-524

Schrand, C., Unal, H., 1998. Hedging and coordinated risk management: Evidence from thrift conversions. Journal of Finance 53, 979-1013

Schwert, G., 2000. Hostility in takeovers: In the eyes of the beholder? Journal of Finance 55, 2599-2640

Shleifer, A., Vishny, R., 1989. Management entrenchment: the case of manager-specific investments. Journal of Financial Economics 25, 123-140

Shleifer, A., Vishny, R.W., 1986. Large shareholders and corporate control. Journal of Political Economy 94, 461-488

Stein, J., 1988. Takeover threats and managerial myopia. Journal of Political Economy 96, 61-80

Straska, M., Waller, G., 2010. Do antitakeover provisions harm shareholders? Journal of 
Corporate Finance 16, 487-497

Subramaniam, C., Daley, L.A., 2000. Free cash flow, golden parachutes, and the discipline of takeover activity. Journal of Business Finance and Accounting 27, 1-36

Tufano, P., 1996. Who manages risk? An empirical examination of risk management practices in the gold mining industry. Journal of Finance 51, 1097-1137

White, H., 1980. A heteroskedasticity-consistent covariance matrix estimator and a direct test for heteroskedasticity. Econometrica 48, 817-838

Yermack, D., 2006. Golden handshakes: Separation pay for retired and dismissed CEOs. Journal of Accounting \& Economics 41, 237-256

Zhou, X., 2001. Understanding the determinants of managerial ownership and the link between ownership and performance: comment. Journal of Financial Economics 62, 559-571 


\section{Table 1. Summary Statistics and Correlations}

This table reports the summary statistics (Panel A) and correlations (Panel B) for the major variables used in the empirical analysis. Definitions of all variables are in the Appendix. The summary statistics for Volat_stk, Idio_stk, Volat_roa, Volat_roe, CEO tenure, CEO age, CEO cash, Size, and Mkt value are reported without taking logs. The summary statistics for Vega and Delta are reported in both their raw format and in logs. CEO cash, Operincome, Mb, Capexp, Rd, Leverage, and Stock return have been winsorized at the $1^{\text {st }}$ and $99^{\text {th }}$ percentiles.

\begin{tabular}{lcccccc}
\hline \multicolumn{7}{c}{ Panel A: Summary Statistics } \\
\hline Variable & Observations & P25 & Mean & Median & P75 & Std \\
\hline GP & 8199 & 0 & 0.66 & 1 & 1 & 0.47 \\
Net G-index & 8199 & 7 & 8.70 & 9 & 10 & 2.48 \\
Volat_stk & 8199 & 0.02 & 0.03 & 0.02 & 0.03 & 0.01 \\
Idio_stk & 8199 & 0.02 & 0.03 & 0.02 & 0.03 & 0.01 \\
Volat_roa & 8183 & 0.01 & 0.02 & 0.01 & 0.02 & 0.04 \\
Volat_roe & 7991 & 0.02 & 0.10 & 0.03 & 0.06 & 0.78 \\
Vega $\left(\$ 10^{3}\right)$ & 8199 & 20.14 & 149.20 & 55.44 & 145.57 & 317.41 \\
Vega $($ log) & 8199 & 3.05 & 3.91 & 4.03 & 4.99 & 1.64 \\
Delta $\left(\$ 10^{3}\right)$ & 8199 & 94.70 & 1370.08 & 242.97 & 668.27 & 13153.40 \\
Delta $($ log) & 8199 & 4.56 & 5.55 & 5.50 & 6.51 & 1.52 \\
CEO tenure (years) & 8199 & 2.61 & 7.76 & 5.26 & 10.67 & 7.32 \\
CEO age (years) & 8199 & 51.00 & 55.43 & 56.00 & 60.00 & 7.30 \\
CEO cash $\left(\$ 10^{6}\right)$ & 8199 & 0.60 & 1.33 & 0.98 & 1.64 & 1.14 \\
Operincome & 8199 & 0.10 & 0.14 & 0.14 & 0.20 & 0.10 \\
Size $\left(\$ 10^{6}\right)$ & 8199 & 504.03 & 5449.02 & 1229.1 & 3745.9 & 22803.28 \\
Mb & 8199 & 1.26 & 2.1 & 1.66 & 2.38 & 1.37 \\
Salesgrow & 8199 & 0.01 & 0.09 & 0.08 & 0.17 & 0.23 \\
Capexp & 8199 & 0 & 0.04 & 0.03 & 0.06 & 0.05 \\
Rd & 8199 & 0 & 0.04 & 0 & 0.05 & 0.06 \\
Leverage & 8199 & 0.07 & 0.22 & 0.21 & 0.33 & 0.17 \\
Segments & 8199 & 3 & 5.23 & 5 & 7 & 3.05 \\
Firm age (years) & 8199 & 10.42 & 25.55 & 20.52 & 33.52 & 19.4 \\
Target & 10873 & 0 & 0.03 & 0 & 0 & 0.17 \\
Stock return & 10873 & -12.01 & 16.45 & 10.64 & 35.72 & 48.9 \\
Mkt value $\left(\$ 10^{6}\right)$ & 10873 & 566.48 & 7627.22 & 1490.04 & 4507.6 & 25609.75 \\
PPE & 10873 & 0.14 & 0.31 & 0.25 & 0.43 & 0.22 \\
Industry target & 10873 & 0 & 0.24 & 0 & 0 & 0.43 \\
\hline & & & & & & \\
\hline
\end{tabular}


Panel B: Correlations

\begin{tabular}{|c|c|c|c|c|c|c|c|c|c|c|c|c|}
\hline & GP & Net G-index & Volat stk & Idio stk & Volat roa & Volat roe & Vega & Delta & Capexp & $\mathrm{Rd}$ & Leverage & Segments \\
\hline GP & 1 & & & & & & & & & & & \\
\hline Net G-index & 0.18 & 1 & & & & & & & & & & \\
\hline Volat_stk & -0.05 & -0.25 & 1 & & & & & & & & & \\
\hline Idio_stk & -0.05 & -0.25 & 0.98 & 1 & & & & & & & & \\
\hline Volat_roa & 0.05 & -0.19 & 0.50 & 0.50 & 1 & & & & & & & \\
\hline Volat_roe & 0.11 & -0.07 & 0.35 & 0.36 & 0.82 & 1 & & & & & & \\
\hline Vega & 0.17 & 0.13 & -0.15 & -0.21 & -0.03 & 0.05 & 1 & & & & & \\
\hline Delta & -0.18 & -0.04 & -0.16 & -0.21 & -0.12 & -0.11 & 0.42 & 1 & & & & \\
\hline Capexp & -0.12 & -0.11 & 0.06 & 0.07 & -0.01 & -0.07 & -0.10 & 0.05 & 1 & & & \\
\hline $\mathrm{Rd}$ & -0.05 & -0.16 & 0.36 & 0.34 & 0.45 & 0.29 & 0.07 & 0.02 & -0.04 & 1 & & \\
\hline Leverage & 0.12 & 0.16 & -0.10 & -0.08 & -0.15 & 0.17 & 0.07 & -0.10 & -0.07 & -0.26 & 1 & \\
\hline Segments & 0.09 & 0.11 & -0.07 & -0.11 & -0.03 & 0.05 & 0.24 & 0.10 & -0.18 & 0.05 & 0.08 & 1 \\
\hline
\end{tabular}




\section{Table 2. Golden Parachutes and Managerial Risk-taking}

These models present the results of pooled OLS regressions for the effect of golden parachutes on managerial risktaking. The sample consists of S\&P 1,500 firms which do not have dual-class stocks and are not in the finance or utility industries from 1992 to 2006. See the Appendix for the definitions of all variables. All models include twodigit SIC industry and year dummies and a constant term, which are not reported to save space. Standard errors are adjusted for heteroskedasticity and clustered at the firm level. t-statistics are reported in parentheses. *, $* *$, and $* * *$ indicate significance at the $10 \%, 5 \%$, and $1 \%$ levels, respectively.

\begin{tabular}{|c|c|c|c|c|}
\hline Dependent variable & $\begin{array}{c}\text { (1) } \\
\text { Volat_stk }\end{array}$ & $\begin{array}{c}\text { (2) } \\
\text { Idio_stk }\end{array}$ & $\begin{array}{c}(3) \\
\text { Volat_roa } \\
\end{array}$ & $\begin{array}{c}\text { (4) } \\
\text { Volat_roe }\end{array}$ \\
\hline GP & $\begin{array}{c}0.000 \\
(0.069)\end{array}$ & $\begin{array}{c}0.000 \\
(0.061)\end{array}$ & $\begin{array}{c}0.005 \\
(0.476)\end{array}$ & $\begin{array}{c}0.017 \\
(1.302)\end{array}$ \\
\hline Net G-index & $\begin{array}{c}-0.003 * * * \\
(-3.198)\end{array}$ & $\begin{array}{c}-0.004 * * * \\
(-3.585)\end{array}$ & $\begin{array}{c}-0.005 * * * \\
(-2.583)\end{array}$ & $\begin{array}{c}-0.005^{* *} \\
(-2.033)\end{array}$ \\
\hline Vega & $\begin{array}{c}-0.007 * * * \\
(-3.157)\end{array}$ & $\begin{array}{c}-0.007 * * * \\
(-3.138)\end{array}$ & $\begin{array}{c}-0.005 \\
(-1.539)\end{array}$ & $\begin{array}{c}-0.006 \\
(-1.357)\end{array}$ \\
\hline Delta & $\begin{array}{c}-0.014 * * * \\
(-4.818)\end{array}$ & $\begin{array}{c}-0.015^{* * *} \\
(-5.217)\end{array}$ & $\begin{array}{c}-0.012 * * \\
(-2.554)\end{array}$ & $\begin{array}{l}-0.012^{*} \\
(-1.847)\end{array}$ \\
\hline CEO tenure & $\begin{array}{c}0.013 * * * \\
(4.181)\end{array}$ & $\begin{array}{c}0.013 * * * \\
(4.132)\end{array}$ & $\begin{array}{c}-0.004 \\
(-0.755)\end{array}$ & $\begin{array}{l}-0.013^{*} \\
(-1.670)\end{array}$ \\
\hline CEO age & $\begin{array}{c}-0.059 * * * \\
(-2.859)\end{array}$ & $\begin{array}{c}-0.054 * * \\
(-2.496)\end{array}$ & $\begin{array}{c}-0.113 * * * \\
(-3.018)\end{array}$ & $\begin{array}{c}-0.120 * * \\
(-2.576)\end{array}$ \\
\hline CEO cash & $\begin{array}{c}-0.006 * * \\
(-2.383)\end{array}$ & $\begin{array}{c}-0.006^{* *} \\
(-2.100)\end{array}$ & $\begin{array}{c}-0.003 \\
(-0.470)\end{array}$ & $\begin{array}{c}0.008 \\
(1.017)\end{array}$ \\
\hline Operincome & $\begin{array}{c}-0.463 * * * \\
(-12.047)\end{array}$ & $\begin{array}{c}-0.481 * * * \\
(-12.560)\end{array}$ & $\begin{array}{c}-0.501 * * * \\
(-7.348)\end{array}$ & $\begin{array}{c}-0.708 * * * \\
(-7.344)\end{array}$ \\
\hline Size & $\begin{array}{c}-0.008 * * \\
(-2.484)\end{array}$ & $\begin{array}{c}-0.014 * * * \\
(-3.950)\end{array}$ & $\begin{array}{c}-0.006 \\
(-1.080)\end{array}$ & $\begin{array}{c}-0.010 \\
(-1.326)\end{array}$ \\
\hline $\mathrm{Mb}$ & $\begin{array}{c}0.011^{* * *} \\
(4.430)\end{array}$ & $\begin{array}{c}0.007 * * * \\
(2.856)\end{array}$ & $\begin{array}{c}0.015 * * * \\
(3.099)\end{array}$ & $\begin{array}{c}0.031 * * * \\
(4.774)\end{array}$ \\
\hline Salesgrow & $\begin{array}{c}0.031 * * \\
(2.578)\end{array}$ & $\begin{array}{l}0.021^{*} \\
(1.750)\end{array}$ & $\begin{array}{c}-0.084 * * * \\
(-3.913)\end{array}$ & $\begin{array}{c}-0.123 * * * \\
(-4.293)\end{array}$ \\
\hline Capexp & $\begin{array}{c}0.150^{* * *} \\
(3.111)\end{array}$ & $\begin{array}{c}0.141 * * * \\
(2.828)\end{array}$ & $\begin{array}{c}-0.022 \\
(-0.186)\end{array}$ & $\begin{array}{c}0.045 \\
(0.362)\end{array}$ \\
\hline $\mathrm{Rd}$ & $\begin{array}{c}0.421 * * * \\
(6.805)\end{array}$ & $\begin{array}{c}0.467 * * * \\
(7.237)\end{array}$ & $\begin{array}{c}0.875 * * * \\
(6.180)\end{array}$ & $\begin{array}{c}1.195 * * * \\
(7.112)\end{array}$ \\
\hline Leverage & $\begin{array}{c}0.054 * * * \\
(2.714)\end{array}$ & $\begin{array}{c}0.071 * * * \\
(3.405)\end{array}$ & $\begin{array}{c}0.111 * * * \\
(3.163)\end{array}$ & $\begin{array}{c}0.682 * * * \\
(11.807)\end{array}$ \\
\hline Segments & $\begin{array}{c}0.001 \\
(1.078)\end{array}$ & $\begin{array}{c}0.001 \\
(0.510)\end{array}$ & $\begin{array}{l}0.004^{*} \\
(1.911)\end{array}$ & $\begin{array}{c}0.003 \\
(1.314)\end{array}$ \\
\hline Firm age & $\begin{array}{c}-0.001 * * * \\
(-5.116)\end{array}$ & $\begin{array}{c}-0.001 * * * \\
(-5.094)\end{array}$ & $\begin{array}{c}-0.000 \\
(-0.911)\end{array}$ & $\begin{array}{l}0.001 * \\
(1.863)\end{array}$ \\
\hline Lagged Volat_stk & $\begin{array}{c}0.668 * * * \\
(60.161)\end{array}$ & & & \\
\hline Lagged Idio_stk & & $\begin{array}{c}0.660 * * * \\
(58.608)\end{array}$ & & \\
\hline Lagged Volat_roa & & & $\begin{array}{c}0.850 * * * \\
(72.119)\end{array}$ & \\
\hline Lagged Volat_roe & & & & $\begin{array}{l}0.853 * * * \\
(103.867)\end{array}$ \\
\hline $\begin{array}{l}\text { Observations } \\
\text { Adjusted } \mathrm{R}^{2}\end{array}$ & $\begin{array}{l}8199 \\
0.80\end{array}$ & $\begin{array}{l}8199 \\
0.80\end{array}$ & $\begin{array}{l}8203 \\
0.85\end{array}$ & $\begin{array}{l}7965 \\
0.83\end{array}$ \\
\hline
\end{tabular}




\section{Table 3. Interactions of Golden Parachutes and CEO Wealth Sensitivities on Risk-taking}

These models present the results of pooled OLS regressions for the interactive effects of golden parachutes and vega and delta on risk-taking. The sample consists of S\&P 1,500 firms which do not have dual-class stocks and are not in the finance or utility industries from 1992 to 2006. See the Appendix for the definitions of all variables. All models include two-digit SIC industry and year dummies and a constant term, which are not reported to save space. Standard errors are adjusted for heteroskedasticity and clustered at the firm level. t-statistics are reported in parentheses. $* * *$, and $* * *$ indicate significance at the $10 \%, 5 \%$, and $1 \%$ levels, respectively.

\begin{tabular}{|c|c|c|c|c|}
\hline Dependent variable & $\begin{array}{c}(1) \\
\text { Volat_stk }\end{array}$ & $\begin{array}{c}\text { (2) } \\
\text { Idio_stk }\end{array}$ & $\begin{array}{c}(3) \\
\text { Volat_roa } \\
\end{array}$ & $\begin{array}{c}(4) \\
\text { Volat_roe }\end{array}$ \\
\hline GP & $\begin{array}{c}0.090 * * * \\
(4.448)\end{array}$ & $\begin{array}{c}0.090 * * * \\
(4.236)\end{array}$ & $\begin{array}{c}0.085 * * \\
(2.321)\end{array}$ & $\begin{array}{c}0.130 * * * \\
(2.650)\end{array}$ \\
\hline Net G-index & $\begin{array}{c}-0.003 * * * \\
(-3.431)\end{array}$ & $\begin{array}{c}-0.004 * * * \\
(-3.792)\end{array}$ & $\begin{array}{c}-0.005 * * * \\
(-2.689)\end{array}$ & $\begin{array}{c}-0.005 * * \\
(-2.132)\end{array}$ \\
\hline GP * Vega & $\begin{array}{c}-0.010 * * * \\
(-2.849)\end{array}$ & $\begin{array}{c}-0.010 * * * \\
(-2.698)\end{array}$ & $\begin{array}{c}0.001 \\
(0.086)\end{array}$ & $\begin{array}{c}-0.001 \\
(-0.153)\end{array}$ \\
\hline Vega & $\begin{array}{c}-0.001 \\
(-0.298)\end{array}$ & $\begin{array}{c}-0.001 \\
(-0.393)\end{array}$ & $\begin{array}{c}-0.004 \\
(-0.891)\end{array}$ & $\begin{array}{c}-0.003 \\
(-0.593)\end{array}$ \\
\hline GP * Delta & $\begin{array}{c}-0.009 * * * \\
(-2.602)\end{array}$ & $\begin{array}{c}-0.009 * * \\
(-2.499)\end{array}$ & $\begin{array}{c}-0.015^{* *} \\
(-2.118)\end{array}$ & $\begin{array}{c}-0.019 * * \\
(-2.178)\end{array}$ \\
\hline Delta & $\begin{array}{c}-0.007 * * \\
(-2.242)\end{array}$ & $\begin{array}{c}-0.009 * * * \\
(-2.693)\end{array}$ & $\begin{array}{c}-0.005 \\
(-0.849)\end{array}$ & $\begin{array}{c}-0.002 \\
(-0.245)\end{array}$ \\
\hline CEO tenure & $\begin{array}{c}0.013 * * * \\
(4.164)\end{array}$ & $\begin{array}{c}0.013 * * * \\
(4.115)\end{array}$ & $\begin{array}{c}-0.004 \\
(-0.728)\end{array}$ & $\begin{array}{l}-0.013^{*} \\
(-1.648)\end{array}$ \\
\hline CEO age & $\begin{array}{c}-0.060 * * * \\
(-2.951)\end{array}$ & $\begin{array}{c}-0.055^{* *} \\
(-2.576)\end{array}$ & $\begin{array}{c}-0.112 * * * \\
(-2.971)\end{array}$ & $\begin{array}{c}-0.119^{* *} \\
(-2.558)\end{array}$ \\
\hline CEO cash & $\begin{array}{c}-0.006^{* *} \\
(-2.243)\end{array}$ & $\begin{array}{l}-0.005^{*} \\
(-1.958)\end{array}$ & $\begin{array}{c}-0.002 \\
(-0.330)\end{array}$ & $\begin{array}{c}0.009 \\
(1.156)\end{array}$ \\
\hline Operincome & $\begin{array}{c}-0.460 * * * \\
(-12.015)\end{array}$ & $\begin{array}{c}-0.478 * * * \\
(-12.526)\end{array}$ & $\begin{array}{c}-0.498 * * * \\
(-7.306)\end{array}$ & $\begin{array}{r}-0.704 * * * \\
(-7.320)\end{array}$ \\
\hline Size & $\begin{array}{c}-0.009 * * * \\
(-2.738)\end{array}$ & $\begin{array}{c}-0.015 * * * \\
(-4.200)\end{array}$ & $\begin{array}{c}-0.007 \\
(-1.174)\end{array}$ & $\begin{array}{c}-0.011 \\
(-1.416)\end{array}$ \\
\hline $\mathrm{Mb}$ & $\begin{array}{c}0.010^{* * *} \\
(3.985)\end{array}$ & $\begin{array}{c}0.006^{* *} \\
(2.398)\end{array}$ & $\begin{array}{c}0.014 * * * \\
(2.935)\end{array}$ & $\begin{array}{c}0.030 * * * \\
(4.584)\end{array}$ \\
\hline Salesgrow & $\begin{array}{c}0.031 * * * \\
(2.586)\end{array}$ & $\begin{array}{l}0.021^{*} \\
(1.760)\end{array}$ & $\begin{array}{c}-0.083 * * * \\
(-3.883)\end{array}$ & $\begin{array}{c}-0.122 * * * \\
(-4.263)\end{array}$ \\
\hline Capexp & $\begin{array}{c}0.148 * * * \\
(3.051)\end{array}$ & $\begin{array}{c}0.139 * * * \\
(2.767)\end{array}$ & $\begin{array}{c}-0.019 \\
(-0.155)\end{array}$ & $\begin{array}{c}0.048 \\
(0.389)\end{array}$ \\
\hline $\mathrm{Rd}$ & $\begin{array}{c}0.440 * * * \\
(7.069)\end{array}$ & $\begin{array}{c}0.484 * * * \\
(7.490)\end{array}$ & $\begin{array}{c}0.884 * * * \\
(6.230)\end{array}$ & $\begin{array}{c}1.208 * * * \\
(7.203)\end{array}$ \\
\hline Leverage & $\begin{array}{c}0.053 * * * \\
(2.655)\end{array}$ & $\begin{array}{c}0.070 * * * \\
(3.356)\end{array}$ & $\begin{array}{c}0.108 * * * \\
(3.084)\end{array}$ & $\begin{array}{r}0.678 * * * \\
(11.767)\end{array}$ \\
\hline Segments & $\begin{array}{c}0.001 \\
(0.980)\end{array}$ & $\begin{array}{c}0.000 \\
(0.413)\end{array}$ & $\begin{array}{l}0.004^{*} \\
(1.866)\end{array}$ & $\begin{array}{c}0.003 \\
(1.279)\end{array}$ \\
\hline Firm age & $\begin{array}{c}-0.001 * * * \\
(-5.007)\end{array}$ & $\begin{array}{c}-0.001 * * * \\
(-4.974)\end{array}$ & $\begin{array}{c}-0.000 \\
(-0.862)\end{array}$ & $\begin{array}{l}0.001^{*} \\
(1.912)\end{array}$ \\
\hline Lagged Volat_stk & $\begin{array}{c}0.664 * * * \\
(60.475)\end{array}$ & & & \\
\hline Lagged Idio_stk & & $\begin{array}{c}0.657 * * * \\
(58.877)\end{array}$ & & \\
\hline Lagged Volat_roa & & & $\begin{array}{c}0.849 * * * \\
(71.934)\end{array}$ & \\
\hline Lagged Volat_roe & & & & $\begin{array}{l}0.853 * * * \\
(103.268)\end{array}$ \\
\hline
\end{tabular}


Observations

Adjusted R ${ }^{2}$
8199

0.80

8203

0.85

7965

0.80

0.83 


\section{Table 4. Golden Parachutes and Takeover Probability}

These models present the results of probit regressions of golden parachutes on the incidence of takeovers. The sample consists of S\&P 1,500 firms which do not have dual-class stocks and are not in the finance or utility industries from 1992 to 2006. See the Appendix for the definitions of all variables. All models include year dummies and a constant term, which are not reported to save space. Model 1 also controls for two-digit SIC industry dummies. Industry adj. X refers to the industry-adjusted variable X, defined as a firm's value of variable X minus the two-digit SIC industry median value of variable X. Standard errors are adjusted for heteroskedasticity and clustered at the firm level. t-statistics are reported in parentheses. ${ }^{*}, * *$, and $* * *$ indicate significance at the $10 \%$, $5 \%$, and $1 \%$ levels, respectively.

\begin{tabular}{|c|c|c|c|}
\hline Dependent variable & $\begin{array}{c}(1) \\
\text { Target }\end{array}$ & $\begin{array}{c}(2) \\
\text { Target }\end{array}$ & $\begin{array}{c}(3) \\
\text { Target }\end{array}$ \\
\hline GP & $\begin{array}{c}0.147^{* *} \\
(2.498)\end{array}$ & $\begin{array}{c}0.159 * * * \\
(2.817)\end{array}$ & $\begin{array}{c}0.155 * * * \\
(2.760)\end{array}$ \\
\hline Net G-index & $\begin{array}{c}0.003 \\
(0.277)\end{array}$ & $\begin{array}{c}-0.002 \\
(-0.166)\end{array}$ & $\begin{array}{c}-0.001 \\
(-0.057)\end{array}$ \\
\hline CEO tenure & $\begin{array}{c}-0.071 * * * \\
(-2.712)\end{array}$ & $\begin{array}{c}-0.078 * * * \\
(-3.085)\end{array}$ & $\begin{array}{c}-0.078 * * * \\
(-3.104)\end{array}$ \\
\hline CEO age & $\begin{array}{c}0.286 \\
(1.404)\end{array}$ & $\begin{array}{c}0.265 \\
(1.302)\end{array}$ & $\begin{array}{c}0.274 \\
(1.353)\end{array}$ \\
\hline Stock return & $\begin{array}{c}-0.002 * * * \\
(-3.045)\end{array}$ & & \\
\hline Industry adj. stock return & & $\begin{array}{c}-0.002 * * * \\
(-3.119)\end{array}$ & $\begin{array}{c}-0.002 * * * \\
(-3.044)\end{array}$ \\
\hline Operincome & $\begin{array}{l}-0.574^{*} \\
(-1.855)\end{array}$ & & \\
\hline Industry adj. operincome & & $\begin{array}{l}-0.504^{*} \\
(-1.686)\end{array}$ & $\begin{array}{c}-0.387 \\
(-1.255)\end{array}$ \\
\hline Mkt value & $\begin{array}{c}0.015 \\
(0.747)\end{array}$ & $\begin{array}{c}0.027 \\
(1.442)\end{array}$ & \\
\hline Industry adj. mkt value & & & $\begin{array}{c}0.014 \\
(0.706)\end{array}$ \\
\hline $\mathrm{Mb}$ & $\begin{array}{l}-0.053^{*} \\
(-1.780)\end{array}$ & $\begin{array}{l}-0.054^{*} \\
(-1.849)\end{array}$ & \\
\hline Industry adj. mb & & & $\begin{array}{l}-0.055^{*} \\
(-1.822)\end{array}$ \\
\hline Leverage & $\begin{array}{c}0.245 \\
(1.548)\end{array}$ & & \\
\hline Industry adj. leverage & & $\begin{array}{c}0.228 \\
(1.448)\end{array}$ & $\begin{array}{c}0.223 \\
(1.421)\end{array}$ \\
\hline PPE & $\begin{array}{c}-0.036 \\
(-0.174)\end{array}$ & $\begin{array}{c}0.041 \\
(0.354)\end{array}$ & \\
\hline Industry adj. PPE & & & $\begin{array}{c}-0.084 \\
(-0.417)\end{array}$ \\
\hline Firm age & $\begin{array}{c}-0.005 * * * \\
(-2.885)\end{array}$ & $\begin{array}{c}-0.006 * * * \\
(-3.576)\end{array}$ & $\begin{array}{c}-0.005 * * * \\
(-3.328)\end{array}$ \\
\hline Industry target & & $\begin{array}{l}0.107^{*} \\
(1.864)\end{array}$ & $\begin{array}{l}0.108^{*} \\
(1.884)\end{array}$ \\
\hline Industry dummies & Yes & No & No \\
\hline Observations & 10184 & 10873 & 10873 \\
\hline Pseudo $\mathrm{R}^{2}$ & 0.08 & 0.06 & 0.06 \\
\hline
\end{tabular}




\section{Table 5. Test of the Takeover Probability Hypothesis}

These models present the results of pooled OLS regressions to test the takeover probability hypothesis, which states that similar to the negative interactive effects of golden parachutes and vega and delta on risk-taking, the interactive effects of the takeover-related component of golden parachutes and vega and delta on risk-taking are also negative and significant. Mp_gp (Rs_gp) is defined as the predicted (residual) component of the regression: $\mathrm{GP}=\alpha+\beta * \mathrm{Mp}+\varepsilon$, where $\mathrm{Mp}$ is the marginal probability of takeovers associated with golden parachutes based on Model 3 of Table 4. The sample consists of S\&P 1,500 firms which do not have dual-class stocks and are not in the finance or utility industries from 1992 to 2006. See the Appendix for the definitions of all other variables. All models include twodigit SIC industry and year dummies and a constant term, which are not reported to save space. Standard errors are adjusted for heteroskedasticity and clustered at the firm level. t-statistics are reported in parentheses. *, **, and *** indicate significance at the $10 \%, 5 \%$, and $1 \%$ levels, respectively.

Panel A. Interactions of the Takeover-related Component of Golden Parachutes and CEO Wealth Sensitivities on Risk-taking

\begin{tabular}{|c|c|c|c|c|}
\hline Dependent variable & $\begin{array}{c}(1) \\
\text { Volat_stk } \\
\end{array}$ & $\begin{array}{c}(2) \\
\text { Idio_stk }\end{array}$ & $\begin{array}{c}(3) \\
\text { Volat_roa } \\
\end{array}$ & $\begin{array}{c}(4) \\
\text { Volat_roe }\end{array}$ \\
\hline Mp_gp & $\begin{array}{c}0.193 * * * \\
(5.324)\end{array}$ & $\begin{array}{c}0.191 * * * \\
(5.065)\end{array}$ & $\begin{array}{c}0.218^{* * *} \\
(3.741)\end{array}$ & $\begin{array}{c}0.323^{* * *} \\
(3.713)\end{array}$ \\
\hline GP & $\begin{array}{c}-0.015 \\
(-1.535)\end{array}$ & $\begin{array}{c}-0.020 * * \\
(-1.974)\end{array}$ & $\begin{array}{c}-0.020 \\
(-1.162)\end{array}$ & $\begin{array}{c}-0.027 \\
(-1.246)\end{array}$ \\
\hline Net G-index & $\begin{array}{c}-0.003 * * * \\
(-3.095)\end{array}$ & $\begin{array}{c}-0.004 * * * \\
(-3.488)\end{array}$ & $\begin{array}{c}-0.005^{* * *} \\
(-2.648)\end{array}$ & $\begin{array}{c}-0.005^{* *} \\
(-2.072)\end{array}$ \\
\hline Mp_gp *Vega & $\begin{array}{c}-0.013 * * \\
(-2.102)\end{array}$ & $\begin{array}{l}-0.011 \\
(-1.624)\end{array}$ & $\begin{array}{c}0.009 \\
(0.792)\end{array}$ & $\begin{array}{c}0.003 \\
(0.253)\end{array}$ \\
\hline Vega & $\begin{array}{c}0.002 \\
(0.605)\end{array}$ & $\begin{array}{c}0.001 \\
(0.166)\end{array}$ & $\begin{array}{c}-0.008 \\
(-1.172)\end{array}$ & $\begin{array}{c}-0.005 \\
(-0.589)\end{array}$ \\
\hline Mp_gp * Delta & $\begin{array}{c}-0.020 * * * \\
(-2.913)\end{array}$ & $\begin{array}{c}-0.019 * * * \\
(-2.638)\end{array}$ & $\begin{array}{c}-0.036 * * * \\
(-2.867)\end{array}$ & $\begin{array}{c}-0.043 * * * \\
(-2.624)\end{array}$ \\
\hline Delta & $\begin{array}{c}-0.001 \\
(-0.114)\end{array}$ & $\begin{array}{c}-0.003 \\
(-0.619)\end{array}$ & $\begin{array}{c}0.008 \\
(1.001)\end{array}$ & $\begin{array}{c}0.013 \\
(1.224)\end{array}$ \\
\hline CEO tenure & $\begin{array}{c}0.014 * * * \\
(4.582)\end{array}$ & $\begin{array}{c}0.015^{* * *} \\
(4.655)\end{array}$ & $\begin{array}{c}-0.001 \\
(-0.227)\end{array}$ & $\begin{array}{c}-0.006 \\
(-0.831)\end{array}$ \\
\hline CEO age & $\begin{array}{c}-0.064 * * * \\
(-3.106)\end{array}$ & $\begin{array}{c}-0.061 * * * \\
(-2.801)\end{array}$ & $\begin{array}{c}-0.120^{* * *} \\
(-3.201)\end{array}$ & $\begin{array}{c}-0.137 * * * \\
(-2.972)\end{array}$ \\
\hline CEO cash & $\begin{array}{c}-0.007 * * \\
(-2.532)\end{array}$ & $\begin{array}{c}-0.006^{* *} \\
(-2.164)\end{array}$ & $\begin{array}{c}-0.003 \\
(-0.471)\end{array}$ & $\begin{array}{c}0.006 \\
(0.775)\end{array}$ \\
\hline Operincome & $\begin{array}{c}-0.444 * * * \\
(-11.814)\end{array}$ & $\begin{array}{c}-0.459 * * * \\
(-12.281)\end{array}$ & $\begin{array}{c}-0.475 * * * \\
(-6.864)\end{array}$ & $\begin{array}{c}-0.654 * * * \\
(-6.851)\end{array}$ \\
\hline Size & $\begin{array}{c}-0.009 * * * \\
(-2.862)\end{array}$ & $\begin{array}{c}-0.015^{* * *} \\
(-4.322)\end{array}$ & $\begin{array}{c}-0.008 \\
(-1.321)\end{array}$ & $\begin{array}{c}-0.011 \\
(-1.479)\end{array}$ \\
\hline $\mathrm{Mb}$ & $\begin{array}{c}0.010 * * * \\
(4.025)\end{array}$ & $\begin{array}{c}0.007 * * * \\
(2.655)\end{array}$ & $\begin{array}{c}0.015^{* * * *} \\
(3.080)\end{array}$ & $\begin{array}{c}0.031 * * * \\
(4.676)\end{array}$ \\
\hline Salesgrow & $\begin{array}{c}0.033 * * * \\
(2.789)\end{array}$ & $\begin{array}{c}0.023 * * \\
(1.963)\end{array}$ & $\begin{array}{c}-0.084 * * * \\
(-3.900)\end{array}$ & $\begin{array}{c}-0.118 * * * \\
(-4.108)\end{array}$ \\
\hline Capexp & $\begin{array}{c}0.144 * * * \\
(2.994)\end{array}$ & $\begin{array}{c}0.136^{* * * *} \\
(2.724)\end{array}$ & $\begin{array}{c}-0.005 \\
(-0.041)\end{array}$ & $\begin{array}{c}0.045 \\
(0.365)\end{array}$ \\
\hline $\mathrm{Rd}$ & $\begin{array}{c}0.448^{* * *} \\
(7.298)\end{array}$ & $\begin{array}{c}0.492 * * * \\
(7.694)\end{array}$ & $\begin{array}{c}0.886^{* * * *} \\
(6.246)\end{array}$ & $\begin{array}{c}1.201 * * * \\
(7.243)\end{array}$ \\
\hline Leverage & $\begin{array}{c}0.047^{* *} \\
(2.415)\end{array}$ & $\begin{array}{c}0.064 * * * \\
(3.095)\end{array}$ & $\begin{array}{c}0.098 * * * \\
(2.775)\end{array}$ & $\begin{array}{c}0.658 * * * \\
(11.496)\end{array}$ \\
\hline Segments & $\begin{array}{c}0.001 \\
(0.880)\end{array}$ & $\begin{array}{c}0.000 \\
(0.308)\end{array}$ & $\begin{array}{l}0.003^{*} \\
(1.821)\end{array}$ & $\begin{array}{c}0.003 \\
(1.285)\end{array}$ \\
\hline Firm age & $\begin{array}{c}-0.001 * * * \\
(-3.985)\end{array}$ & $\begin{array}{c}-0.001 * * * \\
(-3.761)\end{array}$ & $\begin{array}{c}0.000 \\
(0.003)\end{array}$ & $\begin{array}{c}0.001 * * * \\
(2.879)\end{array}$ \\
\hline Lagged Volat_stk & $0.666 * * *$ & & & \\
\hline
\end{tabular}




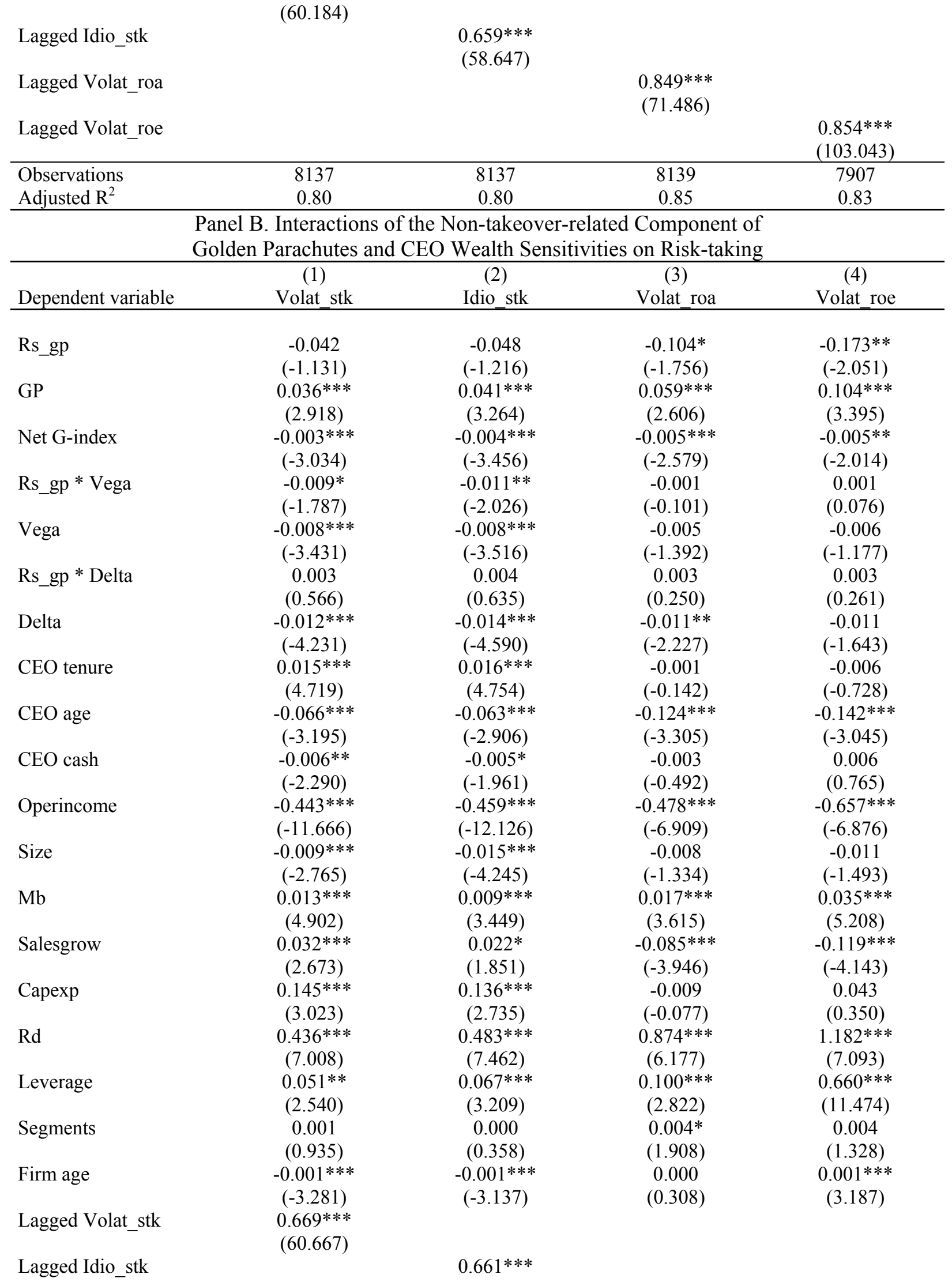




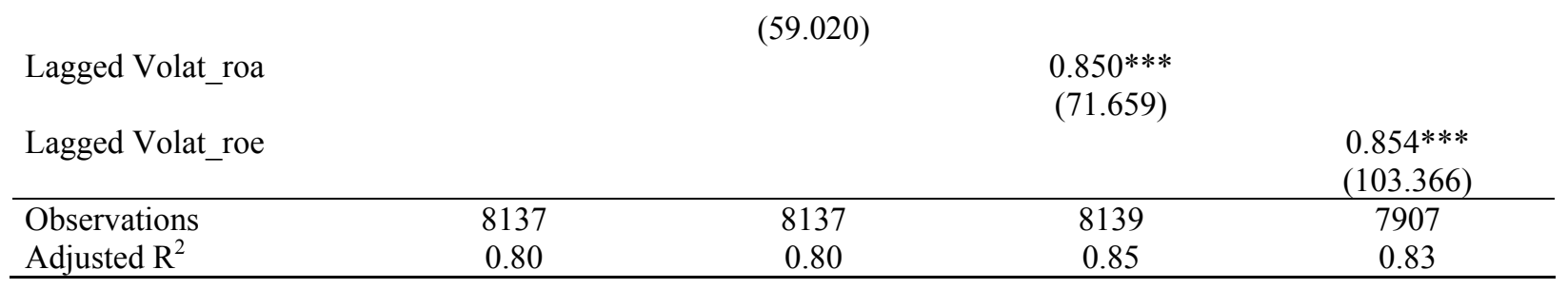




\section{Table 6. Interactions of Takeover Probabilities and CEO Wealth Sensitivities on Risk-taking}

These models present the results of pooled OLS regressions for the interactive effects of the probabilities of takeovers and vega and delta on risk-taking. Tp is the predicted probability of takeovers based on Model 3 of Table 4. The sample consists of S\&P 1,500 firms which do not have dual-class stocks and are not in the finance or utility industries from 1992 to 2006. See the Appendix for the definitions of all other variables. All models include twodigit SIC industry and year dummies and a constant term, which are not reported to save space. Standard errors are adjusted for heteroskedasticity and clustered at the firm level. t-statistics are reported in parentheses. *, ${ }^{* *}$, and ${ }^{* * *}$ indicate significance at the $10 \%, 5 \%$, and $1 \%$ levels, respectively.

\begin{tabular}{|c|c|c|c|c|}
\hline Dependent variable & $\begin{array}{c}\text { (1) } \\
\text { Volat_stk }\end{array}$ & $\begin{array}{c}\text { (2) } \\
\text { Idio_stk }\end{array}$ & $\begin{array}{c}(3) \\
\text { Volat_roa }\end{array}$ & $\begin{array}{c}\text { (4) } \\
\text { Volat_roe }\end{array}$ \\
\hline $\mathrm{Tp}$ & $\begin{array}{c}2.879 * * * \\
(5.133)\end{array}$ & $\begin{array}{c}2.923 * * * \\
(4.972)\end{array}$ & $\begin{array}{c}3.414 * * * \\
(3.774)\end{array}$ & $\begin{array}{c}4.283^{* * *} \\
(3.159)\end{array}$ \\
\hline $\mathrm{Tp} *$ Vega & $\begin{array}{c}-0.141 \\
(-1.460)\end{array}$ & $\begin{array}{l}-0.123 \\
(-1.199)\end{array}$ & $\begin{array}{c}0.019 \\
(0.110)\end{array}$ & $\begin{array}{c}0.071 \\
(0.341)\end{array}$ \\
\hline Vega & $\begin{array}{l}-0.003 \\
(-0.941)\end{array}$ & $\begin{array}{c}-0.004 \\
(-1.211)\end{array}$ & $\begin{array}{c}-0.006 \\
(-1.098)\end{array}$ & $\begin{array}{c}-0.007 \\
(-1.094)\end{array}$ \\
\hline Tp $*$ Delta & $\begin{array}{l}-0.173^{*} \\
(-1.660)\end{array}$ & $\begin{array}{c}-0.104 \\
(-0.959)\end{array}$ & $\begin{array}{c}-0.301 \\
(-1.563)\end{array}$ & $\begin{array}{l}-0.446^{*} \\
(-1.748)\end{array}$ \\
\hline Delta & $\begin{array}{c}-0.008 * * \\
(-2.093)\end{array}$ & $\begin{array}{c}-0.011 * * * \\
(-2.899)\end{array}$ & $\begin{array}{c}-0.004 \\
(-0.575)\end{array}$ & $\begin{array}{c}0.000 \\
(0.045)\end{array}$ \\
\hline GP & $\begin{array}{l}-0.010^{*} \\
(-1.695)\end{array}$ & $\begin{array}{c}-0.014 * * \\
(-2.268)\end{array}$ & $\begin{array}{c}-0.009 \\
(-0.777)\end{array}$ & $\begin{array}{c}0.003 \\
(0.182)\end{array}$ \\
\hline Net G-index & $\begin{array}{c}-0.003 * * * \\
(-2.689)\end{array}$ & $\begin{array}{c}-0.003 * * * \\
(-3.047)\end{array}$ & $\begin{array}{c}-0.005 * * \\
(-2.440)\end{array}$ & $\begin{array}{l}-0.004^{*} \\
(-1.912)\end{array}$ \\
\hline CEO tenure & $\begin{array}{c}0.019 * * * \\
(5.735)\end{array}$ & $\begin{array}{c}0.022 * * * \\
(6.154)\end{array}$ & $\begin{array}{c}0.004 \\
(0.693)\end{array}$ & $\begin{array}{c}-0.001 \\
(-0.173)\end{array}$ \\
\hline CEO age & $\begin{array}{c}-0.082 * * * \\
(-3.856)\end{array}$ & $\begin{array}{c}-0.084 * * * \\
(-3.798)\end{array}$ & $\begin{array}{c}-0.143 * * * \\
(-3.735)\end{array}$ & $\begin{array}{c}-0.157 * * * \\
(-3.299)\end{array}$ \\
\hline CEO cash & $\begin{array}{c}-0.007 * * \\
(-2.508)\end{array}$ & $\begin{array}{c}-0.006^{* *} \\
(-2.066)\end{array}$ & $\begin{array}{c}-0.003 \\
(-0.535)\end{array}$ & $\begin{array}{c}0.005 \\
(0.716)\end{array}$ \\
\hline Operincome & $\begin{array}{c}-0.411 * * * \\
(-10.855)\end{array}$ & $\begin{array}{c}-0.418 * * * \\
(-11.055)\end{array}$ & $\begin{array}{c}-0.438 * * * \\
(-6.335)\end{array}$ & $\begin{array}{c}-0.619 * * * \\
(-6.478)\end{array}$ \\
\hline Size & $\begin{array}{c}-0.010 * * * \\
(-2.981)\end{array}$ & $\begin{array}{c}-0.016^{* * *} \\
(-4.533)\end{array}$ & $\begin{array}{c}-0.009 \\
(-1.458)\end{array}$ & $\begin{array}{c}-0.011 \\
(-1.484)\end{array}$ \\
\hline $\mathrm{Mb}$ & $\begin{array}{c}0.014 * * * \\
(5.191)\end{array}$ & $\begin{array}{c}0.012 * * * \\
(4.365)\end{array}$ & $\begin{array}{c}0.019^{* * * *} \\
(3.640)\end{array}$ & $\begin{array}{c}0.035^{* * *} \\
(4.863)\end{array}$ \\
\hline Salesgrow & $\begin{array}{c}0.035 * * * \\
(2.950)\end{array}$ & $\begin{array}{c}0.026 * * \\
(2.156)\end{array}$ & $\begin{array}{c}-0.082 * * * \\
(-3.822)\end{array}$ & $\begin{array}{c}-0.116^{* * * *} \\
(-4.046)\end{array}$ \\
\hline Capexp & $\begin{array}{c}0.142 * * * \\
(2.949)\end{array}$ & $\begin{array}{c}0.132 * * * \\
(2.659)\end{array}$ & $\begin{array}{c}-0.013 \\
(-0.105)\end{array}$ & $\begin{array}{l}0.040 \\
(0.330)\end{array}$ \\
\hline $\mathrm{Rd}$ & $\begin{array}{c}0.419 * * * \\
(6.824)\end{array}$ & $\begin{array}{c}0.456^{* * *} \\
(7.141)\end{array}$ & $\begin{array}{c}0.862^{* * * *} \\
(6.068)\end{array}$ & $\begin{array}{c}1.168^{* * *} \\
(7.004)\end{array}$ \\
\hline Leverage & $\begin{array}{l}0.035^{*} \\
(1.752)\end{array}$ & $\begin{array}{c}0.046^{* *} \\
(2.220)\end{array}$ & $\begin{array}{l}0.084 * * \\
(2.372)\end{array}$ & $\begin{array}{c}0.647 * * * \\
(11.252)\end{array}$ \\
\hline Segments & $\begin{array}{c}0.001 \\
(0.934)\end{array}$ & $\begin{array}{c}0.000 \\
(0.410)\end{array}$ & $\begin{array}{l}0.004^{*} \\
(1.892)\end{array}$ & $\begin{array}{c}0.003 \\
(1.324)\end{array}$ \\
\hline Firm age & $\begin{array}{l}-0.000^{*} \\
(-1.787)\end{array}$ & $\begin{array}{c}-0.000 \\
(-1.130)\end{array}$ & $\begin{array}{c}0.000 \\
(1.161)\end{array}$ & $\begin{array}{c}0.001 * * * \\
(3.250)\end{array}$ \\
\hline Lagged Volat_stk & $\begin{array}{c}0.669 * * * \\
(60.274)\end{array}$ & & & \\
\hline Lagged Idio_stk & & $\begin{array}{c}0.662 * * * \\
(58.767)\end{array}$ & & \\
\hline Lagged Volat_roa & & & $0.849 * * *$ & \\
\hline
\end{tabular}




\begin{tabular}{lcccc} 
Lagged Volat_roe & & $(71.687)$ & $0.854^{* * * *}$ \\
& & & & $(103.351)$ \\
\hline Observations & 8137 & 8137 & 8139 & 7907 \\
${\text { Adjusted } \mathrm{R}^{2}}$ & 0.80 & 0.80 & 0.85 & 0.83 \\
\hline
\end{tabular}


Table 7. Test of the Entrenchment Hypothesis

These models present the results of pooled OLS regressions conditional on sub-samples characterized by different degree of CEO entrenchment to test the entrenchment hypothesis, which states that the negative interactive effects of golden parachutes and vega and delta are attributable to entrenched CEOs (as indicated by the presence of GPs) reducing risk-taking when faced with greater compensation incentives. The sample consists of S\&P 1,500 firms which do not have dual-class stocks and are not in the finance or utility industries from 1992 to 2006 . High CEO tenure is a dummy variable that equals one if the tenure of the $\mathrm{CEO}$ is above the sample median, and zero otherwise. Low indep director is a dummy variable that equals one if the proportion of independent directors is below the sample median, and zero otherwise. No indep block is a dummy variable that equals one if the board has no independent director with at least $5 \%$ ownership of the firm, and zero otherwise. No inst block is a dummy variable that equals one if the firm has no institutional blockholder with at least $5 \%$ ownership, and zero otherwise. High net G-index is a dummy variable that equals one if the Net G-index of the firm is above the sample median, and zero otherwise. High CEO power is a dummy variable that equals one if the following conditions are met simultaneously: the firm's proportion of independent directors is below the sample median, the CEO shareholdings is above the sample median, the CEO is also the chairman, and the CEO tenure is at least five years, and zero otherwise. See the Appendix for the definitions of other variables. All models include two-digit SIC industry and year dummies and a constant term, which are not reported to save space. Standard errors are adjusted for heteroskedasticity and clustered at the firm level. t-statistics are reported in parentheses. *, **, and *** indicate significance at the $10 \%, 5 \%$, and $1 \%$ levels, respectively.

\begin{tabular}{|c|c|c|c|c|c|c|}
\hline & (1) & (2) & (3) & (4) & (5) & (6) \\
\hline Dependent variable & Volat_stk & Volat_stk & Volat_stk & Volat_stk & Volat_stk & Volat_stk \\
\hline Sample & $\begin{array}{c}\text { High CEO } \\
\text { tenure }=1\end{array}$ & $\begin{array}{c}\text { High CEO } \\
\text { tenure }=0\end{array}$ & $\begin{array}{l}\text { Low indep } \\
\text { directors }=1\end{array}$ & $\begin{array}{l}\text { Low indep } \\
\text { directors }=0\end{array}$ & $\begin{array}{l}\text { No indep } \\
\text { block }=1\end{array}$ & $\begin{array}{l}\text { No indep } \\
\text { block }=0\end{array}$ \\
\hline
\end{tabular}

difference for GP * Vega

p-value for Chow test on statistical

0.898

0.159

0.695

difference for GP * Delta

$$
\begin{aligned}
& \text { GP * Vega } \\
& \text { GP * Delta }
\end{aligned}
$$

GP

Net G-index

Vega

Delta

CEO tenure

CEO age

$\begin{array}{cc}-0.010 * * & -0.013 * * \\ (-2.386) & (-2.293) \\ -0.006 & -0.005 \\ (-1.133) & (-0.842) \\ 0.057 * & 0.096 * * * \\ (1.800) & (3.483) \\ -0.003 * * & -0.004 * * * \\ (-2.257) & (-2.770) \\ 0.000 & -0.001 \\ (0.075) & (-0.293) \\ -0.013 * * * & -0.007 \\ (-2.937) & (-1.439) \\ 0.015 * & 0.008 \\ (1.911) & (1.602) \\ -0.080 * * * & -0.054 * * \\ (-2.714) & (-1.966)\end{array}$

$\begin{array}{ccc}-0.008 & -0.010 * * & -0.017 \\ (-1.477) & (-2.422) & (-0.812) \\ -0.001 & -0.008 & -0.000 \\ (-0.234) & (-1.639) & (-0.023) \\ 0.033 & 0.085 * * * & 0.060 \\ (1.015) & (3.173) & (0.540) \\ -0.003 & -0.003 * * & -0.004 \\ (-1.589) & (-2.308) & (-0.676) \\ -0.008 * * & -0.000 & -0.021 \\ (-1.966) & (-0.135) & (-1.515) \\ -0.015 * * * & -0.009 * * & -0.008 \\ (-2.674) & (-2.224) & (-0.492) \\ 0.020 * * * & 0.014 * * * & -0.002 \\ (3.987) & (4.051) & (-0.109) \\ -0.059 * & -0.064 * * * & -0.013 \\ (-1.805) & (-2.650) & (-0.128)\end{array}$




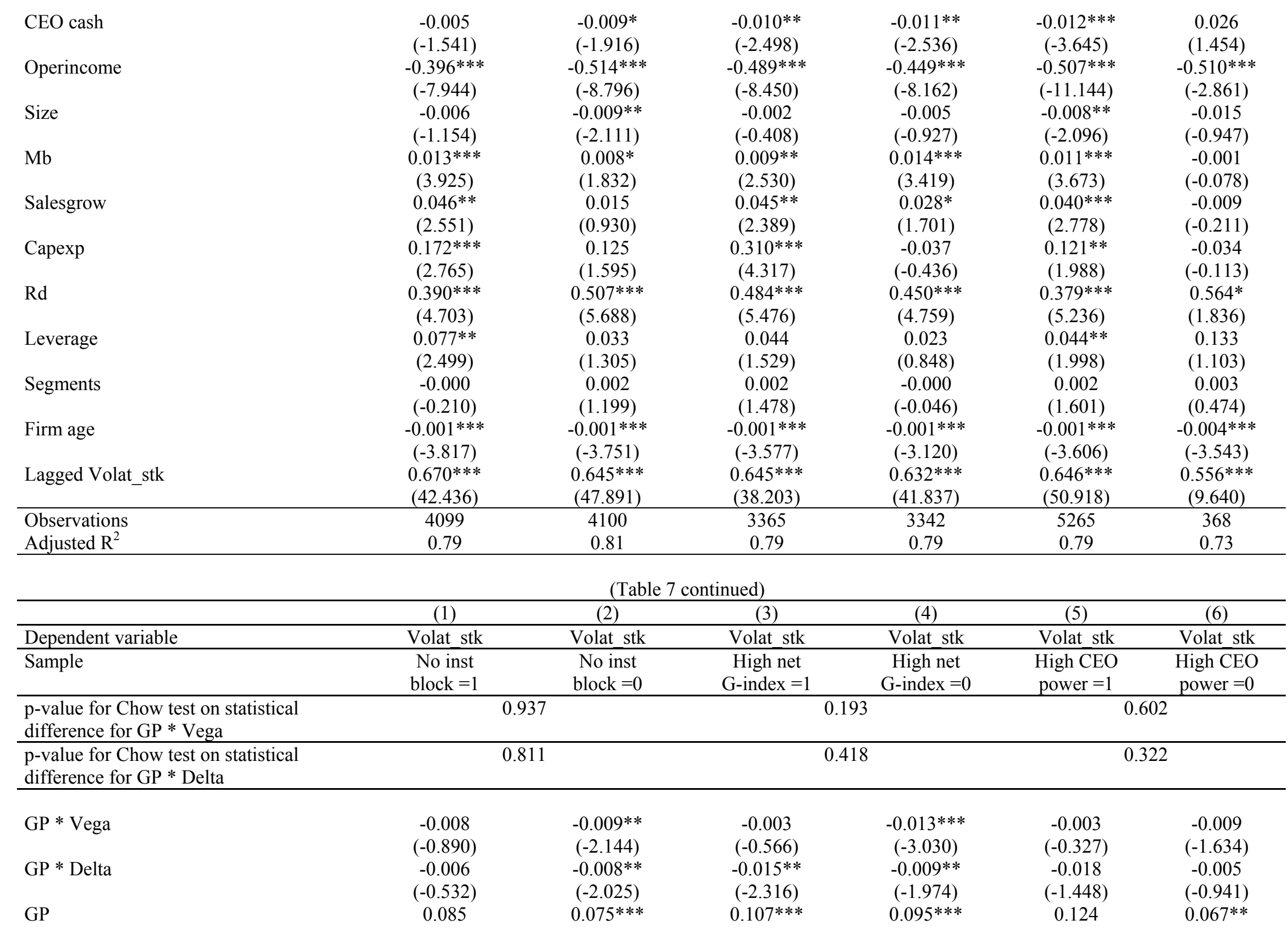




\begin{tabular}{|c|c|c|c|c|c|c|}
\hline & $(1.214)$ & $(3.188)$ & (2.680) & $(3.946)$ & $(1.602)$ & $(2.310)$ \\
\hline \multirow[t]{2}{*}{ Net G-index } & -0.004 & $-0.003 * * *$ & $-0.008 * * *$ & -0.003 & $-0.007 * *$ & $-0.003^{*}$ \\
\hline & $(-1.256)$ & $(-2.953)$ & $(-2.780)$ & $(-1.496)$ & $(-1.977)$ & $(-1.750)$ \\
\hline \multirow[t]{2}{*}{ Vega } & -0.003 & -0.000 & -0.006 & 0.002 & 0.004 & $-0.007^{*}$ \\
\hline & $(-0.468)$ & $(-0.022)$ & $(-1.341)$ & $(0.819)$ & $(0.612)$ & $(-1.795)$ \\
\hline \multirow[t]{2}{*}{ Delta } & $-0.017 * *$ & $-0.010 * * *$ & -0.004 & $-0.007 *$ & -0.005 & $-0.011 * *$ \\
\hline & $(-2.160)$ & $(-2.585)$ & $(-0.709)$ & $(-1.951)$ & $(-0.461)$ & $(-2.043)$ \\
\hline \multirow[t]{2}{*}{ CEO tenure } & $0.029 * * *$ & $0.011 * * *$ & $0.017 * * *$ & $0.011 * * *$ & 0.000 & $0.018 * * *$ \\
\hline & (3.199) & $(3.267)$ & $(3.265)$ & $(2.954)$ & $(0.005)$ & $(3.962)$ \\
\hline \multirow[t]{2}{*}{ CEO age } & -0.083 & $-0.049 * *$ & $-0.087 * *$ & $-0.049^{*}$ & -0.098 & $-0.055^{*}$ \\
\hline & $(-1.235)$ & $(-2.185)$ & $(-2.429)$ & $(-1.914)$ & $(-1.596)$ & $(-1.916)$ \\
\hline \multirow[t]{2}{*}{ CEO cash } & -0.005 & $-0.008 * *$ & -0.005 & $-0.007 * *$ & $-0.018 * *$ & $-0.011 * * *$ \\
\hline & $(-0.906)$ & $(-2.406)$ & $(-1.303)$ & $(-1.987)$ & $(-1.986)$ & $(-2.757)$ \\
\hline \multirow[t]{2}{*}{ Operincome } & $-0.545 * * *$ & $-0.458 * * *$ & $-0.635 * * *$ & $-0.432 * * *$ & $-0.333 * * *$ & $-0.483 * * *$ \\
\hline & $(-4.807)$ & $(-10.835)$ & $(-8.476)$ & $(-9.776)$ & $(-3.387)$ & $(-9.304)$ \\
\hline \multirow{2}{*}{ Size } & 0.001 & $-0.010 * * *$ & $-0.010^{*}$ & $-0.008 * *$ & 0.001 & -0.004 \\
\hline & $(0.125)$ & $(-2.655)$ & $(-1.903)$ & $(-1.981)$ & $(0.060)$ & $(-0.861)$ \\
\hline \multirow[t]{2}{*}{$\mathrm{Mb}$} & 0.011 & $0.012 * * *$ & $0.021 * * *$ & $0.007 * *$ & $0.017 * *$ & $0.013 * * *$ \\
\hline & $(1.595)$ & $(4.027)$ & $(4.084)$ & $(2.286)$ & $(2.308)$ & $(3.556)$ \\
\hline \multirow[t]{2}{*}{ Salesgrow } & -0.027 & $0.061 * * *$ & 0.014 & $0.043 * * *$ & 0.007 & $0.031 * *$ \\
\hline & $(-1.067)$ & $(4.480)$ & $(0.606)$ & $(3.074)$ & $(0.188)$ & $(2.161)$ \\
\hline \multirow[t]{2}{*}{ Capexp } & $0.308 * *$ & $0.144 * * *$ & $0.149 *$ & $0.155^{* *}$ & 0.063 & 0.029 \\
\hline & $(2.026)$ & $(2.645)$ & $(1.658)$ & $(2.568)$ & $(0.396)$ & $(0.375)$ \\
\hline \multirow[t]{2}{*}{$\mathrm{Rd}$} & $0.376^{*}$ & $0.425 * * *$ & $0.525 * * *$ & $0.415^{* * *}$ & $0.632 * * *$ & $0.451 * * *$ \\
\hline & $(1.800)$ & (6.194) & $(3.283)$ & $(6.153)$ & $(3.529)$ & $(5.232)$ \\
\hline \multirow[t]{2}{*}{ Leverage } & -0.037 & $0.072 * * *$ & 0.051 & $0.061 * *$ & 0.072 & 0.007 \\
\hline & $(-0.692)$ & $(3.191)$ & $(1.478)$ & $(2.553)$ & $(1.139)$ & $(0.285)$ \\
\hline \multirow[t]{2}{*}{ Segments } & 0.003 & 0.001 & -0.001 & 0.002 & 0.001 & -0.000 \\
\hline & $(0.974)$ & $(1.104)$ & $(-0.427)$ & $(1.221)$ & $(0.281)$ & $(-0.380)$ \\
\hline \multirow[t]{2}{*}{ Firm age } & $-0.002 * * *$ & $-0.001 * * *$ & $-0.001 * * *$ & $-0.001 * * *$ & $-0.002 * * *$ & $-0.001 * * *$ \\
\hline & $(-4.156)$ & $(-3.779)$ & $(-2.998)$ & $(-3.672)$ & $(-3.498)$ & $(-3.316)$ \\
\hline \multirow[t]{2}{*}{ Lagged Volat_stk } & $0.642 * * *$ & $0.661 * * *$ & $0.625 * * *$ & $0.671 * * *$ & $0.608 * * *$ & $0.639 * * *$ \\
\hline & $(17.158)$ & $(59.655)$ & $(34.401)$ & $(49.528)$ & $(17.394)$ & $(46.456)$ \\
\hline Observations & 1116 & 6537 & 3078 & 5121 & 828 & 3957 \\
\hline Adjusted $\mathrm{R}^{2}$ & 0.82 & 0.79 & 0.76 & 0.81 & 0.76 & 0.80 \\
\hline
\end{tabular}




\section{Table 8. Fixed-Effects Regressions of the Interactions of Golden Parachutes and CEO Wealth Sensitivities on Risk-taking}

These models employ fixed-effects (FE) regressions to examine the robustness of the results with respect to the takeover probability hypothesis. Mp_gp is defined as the predicted component of the regression: $\mathrm{GP}=\alpha+\beta^{*} \mathrm{Mp}+\varepsilon$, where $\mathrm{Mp}$ is the marginal probability of takeovers associated with golden parachutes based on Model 3 of Table 4 . The sample consists of S\&P 1,500 firms which do not have dual-class stocks and are not in the finance or utility industries from 1992 to 2006. See the Appendix for the definitions of all other variables. All models include year dummies and a constant term, which are not reported to save space. Standard errors are adjusted for heteroskedasticity and clustered at the firm level. t-statistics are reported in parentheses. $*, * *$, and $* * *$ indicate significance at the $10 \%, 5 \%$, and $1 \%$ levels, respectively.

\begin{tabular}{|c|c|c|c|c|}
\hline & (1) & (2) & (3) & (4) \\
\hline Dependent variable & Volat_stk & Idio_stk & Volat_roa & Volat_roe \\
\hline \multirow[t]{2}{*}{ Mp_gp } & $0.165 * * *$ & $0.131 * *$ & $0.196 * * *$ & $0.263 * * *$ \\
\hline & $(3.230)$ & $(2.450)$ & $(2.681)$ & $(2.864)$ \\
\hline \multirow[t]{2}{*}{ GP } & -0.009 & -0.007 & 0.010 & 0.021 \\
\hline & $(-0.591)$ & $(-0.482)$ & $(0.383)$ & $(0.706)$ \\
\hline \multirow[t]{2}{*}{ Net G-index } & -0.005 & -0.005 & 0.001 & -0.001 \\
\hline & $(-1.218)$ & $(-1.282)$ & $(0.180)$ & $(-0.110)$ \\
\hline \multirow[t]{2}{*}{ Mp_gp * Vega } & -0.007 & 0.000 & 0.010 & -0.004 \\
\hline & $(-0.760)$ & $(0.023)$ & $(0.672)$ & $(-0.248)$ \\
\hline \multirow[t]{2}{*}{ Vega } & $-0.011 *$ & $-0.016 * *$ & -0.016 & -0.012 \\
\hline & $(-1.665)$ & $(-2.321)$ & $(-1.442)$ & $(-0.922)$ \\
\hline \multirow[t]{2}{*}{ Mp_gp $*$ Delta } & $-0.023 * *$ & $-0.022 * *$ & $-0.039 * *$ & -0.027 \\
\hline & $(-2.345)$ & $(-2.064)$ & $(-2.296)$ & $(-1.353)$ \\
\hline \multirow[t]{2}{*}{ Delta } & 0.003 & -0.003 & 0.008 & -0.000 \\
\hline & $(0.365)$ & $(-0.340)$ & $(0.603)$ & $(-0.008)$ \\
\hline \multirow[t]{2}{*}{ CEO tenure } & $0.011 * *$ & $0.010 *$ & $-0.026 * * *$ & $-0.030 * * *$ \\
\hline & $(2.223)$ & $(1.960)$ & $(-3.074)$ & $(-2.725)$ \\
\hline \multirow[t]{2}{*}{ CEO age } & -0.047 & -0.019 & 0.027 & -0.013 \\
\hline & $(-1.230)$ & $(-0.469)$ & $(0.417)$ & $(-0.153)$ \\
\hline \multirow[t]{2}{*}{ CEO cash } & $-0.012 * * *$ & $-0.011 * *$ & 0.002 & 0.006 \\
\hline & $(-2.877)$ & $(-2.555)$ & $(0.206)$ & $(0.571)$ \\
\hline \multirow[t]{2}{*}{ Operincome } & $-0.403 * * *$ & $-0.394 * * *$ & $-0.615 * * *$ & $-0.545 * * *$ \\
\hline & $(-6.333)$ & $(-6.077)$ & $(-5.066)$ & $(-3.180)$ \\
\hline \multirow[t]{2}{*}{ Size } & $-0.045 * * *$ & $-0.062 * * *$ & $-0.052 * *$ & $-0.106 * * *$ \\
\hline & $(-4.134)$ & $(-5.419)$ & $(-2.482)$ & $(-3.822)$ \\
\hline \multirow[t]{2}{*}{$\mathrm{Mb}$} & $0.011 * * *$ & 0.003 & 0.004 & $0.023 * *$ \\
\hline & $(2.776)$ & $(0.624)$ & $(0.422)$ & $(2.143)$ \\
\hline \multirow[t]{2}{*}{ Salesgrow } & $0.036^{* * *}$ & $0.032 * *$ & -0.030 & $-0.056^{*}$ \\
\hline & $(2.707)$ & $(2.382)$ & $(-1.283)$ & $(-1.759)$ \\
\hline \multirow[t]{2}{*}{ Capexp } & 0.041 & 0.017 & $-0.413 * * *$ & $-0.541 * * *$ \\
\hline & $(0.491)$ & $(0.194)$ & $(-2.926)$ & $(-3.237)$ \\
\hline \multirow[t]{2}{*}{$\mathrm{Rd}$} & 0.101 & 0.142 & $1.392 * * *$ & $2.166 * * *$ \\
\hline & $(0.783)$ & $(1.096)$ & $(3.902)$ & $(4.890)$ \\
\hline \multirow[t]{2}{*}{ Leverage } & $0.090 * * *$ & $0.114 * * *$ & $0.114^{*}$ & $0.890 * * *$ \\
\hline & $(2.632)$ & $(3.192)$ & $(1.840)$ & $(7.951)$ \\
\hline \multirow[t]{2}{*}{ Segments } & $0.005 * * *$ & $0.005 * *$ & 0.005 & $0.010 * *$ \\
\hline & $(2.893)$ & $(2.572)$ & $(1.522)$ & $(2.426)$ \\
\hline \multirow[t]{2}{*}{ Firm age } & -0.010 & -0.014 & 0.009 & 0.036 \\
\hline & $(-0.634)$ & $(-0.992)$ & $(0.411)$ & $(1.193)$ \\
\hline \multirow[t]{2}{*}{ Lagged Volat_stk } & $0.349 * * *$ & & & \\
\hline & $(20.273)$ & & & \\
\hline Lagged Idio_stk & & $\begin{array}{c}0.331 * * * \\
(18.568)\end{array}$ & & \\
\hline
\end{tabular}




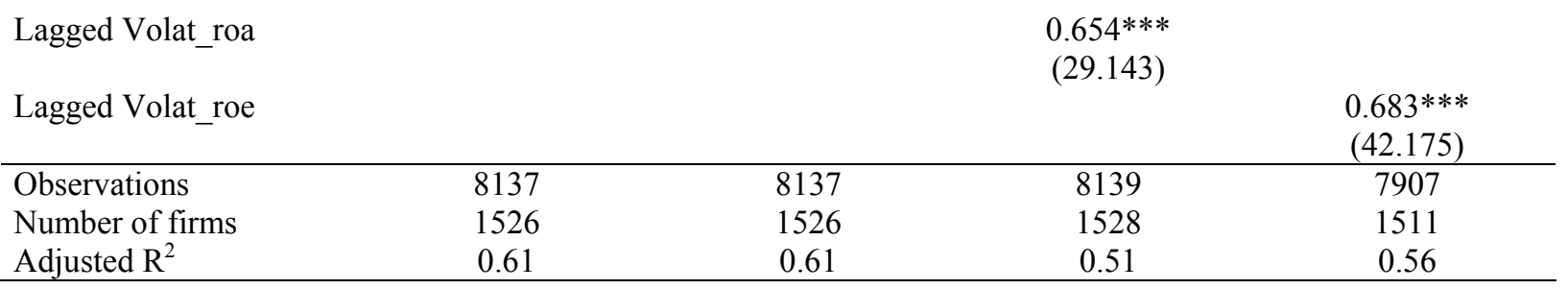

